\title{
Presence of Androgen Receptor Variant in Neuronal Lipid Rafts
}

\author{
Jo Garza-Contreras, Phong Duong, Brina D. Snyder, Derek A. Schreihofer, and Rebecca L. Cunningham
}

DOI:http://dx.doi.org/10.1523/ENEURO.0109-17.2017

Center for Alzheimer's and Neurodegenerative Disease Research and Center for Neuroscience Discovery, Institute for Healthy Aging, University of North Texas Health Science Center, Fort Worth, TX 76107

\begin{abstract}
Fast, nongenomic androgen actions have been described in various cell types, including neurons. However, the receptor mediating this cell membrane-initiated rapid signaling remains unknown. This study found a putative androgen receptor splice variant in a dopaminergic N27 cell line and in several brain regions (substantia nigra pars compacta, entorhinal cortex, and hippocampus) from gonadally intact and gonadectomized (young and middleaged) male rats. This putative splice variant protein has a molecular weight of $45 \mathrm{kDa}$ and lacks an N-terminal domain, indicating it is homologous to the human AR45 splice variant. Interestingly, AR45 was highly expressed in all brain regions examined. In dopaminergic neurons, AR45 is localized to plasma membrane lipid rafts, a microdomain involved in cellular signaling. Further, AR45 protein interacts with membrane-associated G proteins $\mathrm{G} \alpha \mathrm{q}$ and $\mathrm{G} \alpha \mathrm{O}$. Neither age nor hormone levels altered AR45 expression in dopaminergic neurons. These results provide the first evidence of AR45 protein expression in the brain, specifically plasma membrane lipid rafts. AR45 presence in lipid rafts indicates that it may function as a membrane androgen receptor to mediate fast, nongenomic androgen actions.
\end{abstract}

Key words: Androgen receptor; caveolin; G proteins; lipid rafts; membrane; signaling

\section{Significance Statement}

Evidence has been building for the existence of a membrane androgen receptor, but the nature of this receptor remains elusive. We predicted that the membrane androgen receptor is a splice variant that is present in lipid raft microdomains within the neuronal plasma membrane. Indeed, an androgen receptor that is lacking an N-terminal domain and complexed to $\mathrm{G} \alpha q$ and $\mathrm{G} \alpha \mathrm{o} \mathrm{G}$ proteins was highly expressed in lipid rafts in dopaminergic neurons. This putative splice variant provides a potential target for mediating androgen's nongenomic actions.

\section{Introduction}

In addition to peripheral expression in many tissues, the androgen receptor (AR) is expressed in many areas of the brain, including brain regions not involved in regulating

Received March 27, 2017; accepted August 14, 2017; First published August 22, 2017

Authors report no conflicts of interest.

Author contributions: JG-C and RLC designed the study; JG-C, PD, BDS, and DAS conducted the research; JG-C, DAS, and RLC analyzed the data; RLC wrote the paper.

This study was funded by the National Institute of Neurological Disorders and Stroke (R01 NS088514) to RLC.

Acknowledgments: We thank Drs. J. Thomas Cunningham, Robert Barber, and Robert Luedtke for their technical assistance. classic endocrine functions (e.g., substantia nigra, hippocampus, entorhinal cortex; McEwen, 1980; Song et al., 1991; Kerr et al., 1995; Kritzer, 1997; Kritzer and Creutz, 2008; Sarkey et al., 2008). The classic intracellular AR is

Correspondence should be addressed to Rebecca L. Cunningham, PhD, University of North Texas Health Science Center, Institute for Healthy Aging, 3500 Camp Bowie Blvd., Fort Worth, TX 76107. Email: rebecca.cunningham@unthsc.edu.

DOI:http://dx.doi.org/10.1523/ENEURO.0109-17.2017 Copyright (C) 2017 Garza-Contreras et al.

This is an open-access article distributed under the terms of the Creative Commons Attribution 4.0 International license, which permits unrestricted use, distribution and reproduction in any medium provided that the original work is properly attributed. 
involved in genomic transcription (Ozanne et al., 2000; Edwards and Bartlett, 2005; Smith and Toft, 2008; Green et al., 2012). This AR is composed of eight exons that code for a $110-\mathrm{kDa}$ protein belonging to the steroid receptor superfamily of nuclear transcription factors (Claessens et al., 2008). The classic AR has four distinct regions: a regulatory $\mathrm{NH}_{2}$ terminal domain (NTD; Ferro et al., 2002; Ding et al., 2004, 2005; Callewaert et al., 2006; Claessens et al., 2008), a DNA binding domain (DBD), a hinge domain, and a ligand binding domain (LBD) extending to the C-terminal domain (CTD; Claessens et al., 2008).

Evidence for a nongenomic membrane AR (mAR) has been accumulating since the 1990s. Investigators have found that even cell-impermeable androgens can have fast cellular effects (Steinsapir et al., 1991; Gorczynska and Handelsman, 1995; Benten et al., 1999; Estrada et al., 2003, 2006; Holmes et al., 2013). Rapid membrane effects of androgens, via testosterone conjugated to bovine serum albumin (BSA), have been observed in neuronal cell lines (N27 and SH-SY5Y), resulting in an oscillatory pattern of intracellular calcium release that is unaffected by AR antagonists or knockdown of the classic intracellular AR (Estrada et al., 2006; Holmes et al., 2013). Unlike the classic AR, the mAR has not been cloned or purified. Different theories have proposed that the mAR could be the classic AR anchored to the plasma membrane (Pedram et al., 2007), an unknown AR (Hatzoglou et al., 2005), or even a splice variant of the classic AR (Foradori et al., 2008).

Numerous AR splice variants have been found outside the nervous system. These variants originate from alternative splicing at different promoters and thus increase AR complexity and biological functions (Modrek and Lee, 2002; Roberts and Smith, 2002; Stamm, 2002; AhrensFath et al., 2005; Jagla et al., 2007; Hu et al., 2012). Most of these AR splice variants have a truncated LBD in the CTD, which can result in a constitutively active AR (Sun et al., 2010; Watson et al., 2010; Hu et al., 2012). In contrast to the loss of LBD, some of these AR splice variants exhibit partial to full loss of the $\mathrm{NH}_{2}$ regulatory domain. For example, both AR splice variants (AR8 and AR45) have truncated NTD (Jenster et al., 1991; Ikonen et al., 1998; Ahrens-Fath et al., 2005; Yang et al., 2011).

The AR splice variant, AR45, is the least understood variant and has been characterized only in humans. This splice variant lacks the entire NTD (exon 1). This deletion decreases the protein molecular weight of AR from 110 to $45 \mathrm{kDa}$ (Ahrens-Fath et al., 2005). Functionally, in the periphery, AR45 binds androgens via LBD and translocates to the nucleus. It can homodimerize with other AR45 receptors or heterodimerize with classic AR. AR45 can act as a negative modulator of AR activity via competitive inhibition of AREs by homodimers or by interfering with coactivator recruitment necessary for AR activity (Jenster et al., 1991; Ikonen et al., 1998; Ahrens-Fath et al., 2005). AR45 is expressed in multiple tissues, such as muscle, lung, heart, breast, uterus, and prostate (Ahrens-Fath et al., 2005; Weiss et al., 2007; Wu et al., 2008). Although AR45 protein expression was not observed in total brain homogenate (Ahrens-Fath et al.,
2005), a recent study found low mRNA expression of AR45 in human brain tissue that was commercially obtained from an aged population (Hu et al., 2014). Neuronal function of AR45 is unknown.

To determine whether the putative mAR could be AR45 in different brain regions (substantia nigra pars compacta, CA1 region of the hippocampus, and the second layer of the entorhinal cortex), we measured protein expression of AR using antibodies targeting the CTD and NTD of the AR. Because neuronal mAR has been associated with intracellular calcium signaling (Steinsapir et al., 1991; Gorczynska and Handelsman, 1995; Benten et al., 1999; Estrada et al., 2003, 2006; Holmes et al., 2013), we examined if the mAR complexed with $G$ proteins.

\section{Materials and Methods}

\section{Reagents}

Testosterone (A6950-000) was obtained from Steraloids. Goat anti-rabbit (sc-2004), androgen receptor C-19 (sc-815), androgen receptor N-20 (sc-816), AR441 (sc-7305), AR N20P (sc-515856), AR C19P (sc-515863),

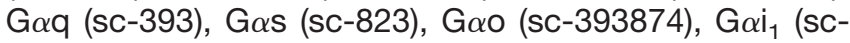
391), $\mathrm{G \alpha i}_{2}$ (sc-13534), and $\mathrm{G} \alpha \mathrm{i}_{3}$ (sc-262) antibodies were obtained from Santa Cruz Biotechnologies. Flotillin (3253) and caveolin-1 (3267) antibodies were obtained from Cell Signaling Technology. Alexa Fluor 594 antibody was purchased from Jackson ImmunoResearch Laboratories. GAPDH (GT239) antibody was obtained from GeneTex. Biotinylated anti-rabbit IgG (BA-1000) was purchased from Vector Laboratories. Androgen R/NR3C4 (AB58761) was obtained from R\&D Systems. DMSO was purchased from VWR. RPMI 1640, penicillin-streptomycin (PS), and trichloroacetic acid (BDH9310) were purchased from VWR. Fetal bovine serum (FBS) and PBS were obtained from Corning. Charcoal-stripped FBS (CS-FBS) was purchased from Atlanta Biologicals. Mounting medium was obtained from Vector Laboratories $(\mathrm{H}-1200)$. SuperSignal West Pico/Femto chemiluminescent substrates, dithiothreitol (DTT), and Clean Blot IP Detection Reagent (PI21230) were obtained from Thermo Fisher Scientific. Deoxycholic acid (D-6750), inactin (T133), horse serum (H1138), and Triton X-100 were purchased from SigmaAldrich. Tris, Any KD polyacrylamide gel, Tris-glycine buffer, and PVDF membranes were purchased from Bio-Rad. Total testosterone ELISA (RTC001R) was purchased from BioVendor. Testosterone was made using an ethanol vehicle (final concentration of ethanol $<0.001 \%$ ).

\section{Animals}

Experiments were conducted on young adult $(3 \mathrm{mo})$ or middle-aged retired breeder (9-12 mo) male SpragueDawley rats (Charles River). Animals were either gonadally intact or were gonadectomized to remove circulating gonadal hormones. Rats were individually housed in a temperature-controlled environment on a 12:12-h lightdark cycle. All rats had ad libitum access to food and water. Animals were weighed at the time of surgery and at death. All experimental procedures were approved by the University of North Texas Health Science Center IACUC in accordance with the guidelines of the Public Health Ser- 
vice, the American Physiologic Society, and the Society for Neuroscience for animal care and use.

\section{Gonadectomy}

Under $2.5 \%$ isoflurane, a midline scrotal incision was made to expose the spermatic cord. The spermatic cord was tied off with sterile sutures, and the cord was cut distal to the thread to remove the testes. The incision was closed with sterile absorbable sutures (Cunningham et al., 2011).

\section{Micropunch tissue dissection}

One week after surgery, each rat was anesthetized with $2.5 \%$ isoflurane and decapitated. The brain was removed from the skull, rinsed in ice-cold PBS, and placed into a brain matrix (Braintree Scientific) on ice. Using razor blades, the brain was cut into 1-mm coronal sections. The razor blades were placed on dry ice to freeze the freshly cut brain sections. Punches were obtained from the SN pars compacta $(-5.30 \mathrm{~mm}$ from bregma), second layer of the entorhinal cortex (ETC; $-5.30 \mathrm{~mm}$ from bregma), and the CA1 layer of the dorsal hippocampus $(-4.52 \mathrm{~mm}$ from bregma) using 1 -ml syringes with a 20 -gauge blunt needle (Snyder et al., 2017). Samples were placed into microcentrifuge tubes, snap-frozen on dry ice, and stored at $-80^{\circ} \mathrm{C}$ or immediately homogenized into whole-cell lysates.

\section{In vitro cell culture}

The immortalized neuronal cell line $1 \mathrm{RB}^{\mathrm{A}} \mathrm{AN}_{27}$ (N27), derived from fetal rat mesencephalic tissue, is positive for tyrosine hydroxylase expression $\left(\mathrm{TH}^{+}\right.$; Clarkson et al., 1999; Anantharam et al., 2007; Carvour et al., 2008). N27 cells were cultured and maintained at $37^{\circ} \mathrm{C}$ in $5 \% \mathrm{CO}_{2}$. Medium used was RPMI 1640 supplemented with $10 \%$ FBS and 1\% PS. N27 cells were used only in passages 13-19. Before hormone treatment for whole-cell lysate experiments, the medium was switched to RPMI 1640 with CS-FBS to avoid confounding from the presence of hormones in the serum. Cells were exposed to testosterone $(100 \mathrm{nM})$ or vehicle control for $18 \mathrm{~h}$ and collected for protein. The testosterone concentration used in this study was $100 \mathrm{nM}$, representing the high end of the normal testosterone range in men (Mooradian et al., 1987; Kelly et al., 1999; Smith et al., 2000; Zitzmann et al., 2002).

\section{Whole cell lysates}

For in vitro preparations, N27 cells were plated in $100 \times$ $20-\mathrm{mm}$ plates at a density of $8.0 \times 10^{4}$ cells per plate. After treatments, cells were washed with PBS and lysed using a cocktail of NP40 and phosphatase inhibitors (1: $100)$ on ice. For in vivo preparations, brain region micropunches were incubated with RIPA homogenization buffer with DTT $(1 \mu \mathrm{M})$, EDTA $(1 \mathrm{mM})$, and protease and phosphatase inhibitors $(1: 200)$ for $30 \mathrm{~min}$ on ice, sonicated (QSonica) at 20\% amplitude, and pulsed 3 times for $3 \mathrm{~s}$. Next, lysates were centrifuged at $4^{\circ} \mathrm{C}$ for $20 \mathrm{~min}$ at $12,000 \times g$. Protein concentrations were determined using the BCA assay (Thermo Fisher Scientific) according to the manufacturer's instructions.

\section{Detergent-free cellular fractionation and sucrose density analysis of membrane lipid rafts}

N27 cells were plated in $100 \times 20-\mathrm{mm}$ plates at a density of $8.0 \times 10^{4}$ cells per plate. After treatments, cells were washed with PBS and lysed with a cocktail of hypotonic homogenization buffer and phosphatase inhibitors $(1: 100)$ on ice. Each sample $(n)$ consisted of two $100 \times 20-\mathrm{mm}$ plates. For micropunches, a total of 0.025 $\mathrm{g}$ of $\mathrm{SN}$ tissue was homogenized in hypotonic homogenization using a sonicator to homogenize the tissue. After homogenization, cellular fractionation followed by sucrose density analysis of membrane lipid rafts was performed (Jeske et al., 2003, 2004). Cell lysate from either N27 cells or micropunches was centrifuged at $1000 \times g$ for $5 \mathrm{~min}$ at $4^{\circ} \mathrm{C}$ to separate the nuclei. The supernatant was centrifuged at $16,000 \times g$ for $30 \mathrm{~min}$ at $4^{\circ} \mathrm{C}$ to separate the cytosolic proteins from the mitochondria, Golgi fragments, and the plasma membrane. The pellet was then resuspended in homogenization buffer supplemented with $500 \mathrm{mM} \mathrm{Na}_{2} \mathrm{CO}_{3}$ (Song et al., 1996). The resuspended membrane pellet was placed into a sucrose flotation-gradient fraction using 5\%/35\%/45\% discontinuous gradient that was spun at $175,000 \times g$ for $18 \mathrm{~h}$ at $4^{\circ} \mathrm{C}$ in an Optima ultracentrifuge Model LE-80K (Beckman Coulter) using a swing bucket rotor (SW 50.1; Beckman Coulter). After the high-speed centrifugation, equalvolume fractions were taken from the top layer of the gradient, resulting in nine fractions (low-density proteins at the top gradient layers to high-density proteins at the bottom gradient layers). Protein was precipitated using the trichloroacetic acid (TCA) method (Link and LaBaer, 2011). The pellet was incubated in $0.15 \%$ deoxycholic acid and then $72 \%$ trichloroacetic acid, followed by $16,000 \times g$ centrifugation for $30 \mathrm{~min}$ at room temperature. The pellet was resuspended in RIPA lysis buffer, Laemmli loading buffer, and $2 \mathrm{M}$ Tris. The sample was loaded into polyacrylamide gels for electrophoresis and Western blot protein analysis. Lipid raft experiments were replicated three times. Only frozen samples were used to decrease AR fragment protein expression (Fig. 1A).

\section{Coimmunoprecipitation}

Because $\mathrm{C}^{1} 9^{+} / \mathrm{N}^{2} \mathrm{O}^{-} \mathrm{AR}$ protein expression at $45 \mathrm{kDa}$ was observed only in the membrane fraction (not the cytosol or nuclear fractions), whole-cell lysates were used. Protein $(25 \mu \mathrm{g})$ was incubated overnight at $4^{\circ} \mathrm{C}$ in a cocktail containing RIPA lysis buffer and $1 \mu \mathrm{g}$ primary antibody (AR C-19 or $\mathrm{G} \alpha \mathrm{q}$ ). A Sepharose bead slurry was coupled to each sample by incubating at $4^{\circ} \mathrm{C}$ overnight. Samples were washed, eluted, and resuspended in $4 \times$ Laemmli buffer. To avoid IgG band interference, the blot was incubated with Clean Blot IP Detection Reagent HRP, per the manufacturer's instructions. Coimmunoprecipitation experiments were replicated four times. Only frozen samples were used to decrease AR fragment protein expression (Fig. 1A)

\section{Western blot}

Equal amounts (20 $\mu \mathrm{g}$ protein) of denatured whole cell lysates, micropunch tissues, cellular fractions, or lipid raft fractions were loaded into a Bio-Rad Any KD polyacryl- 
A
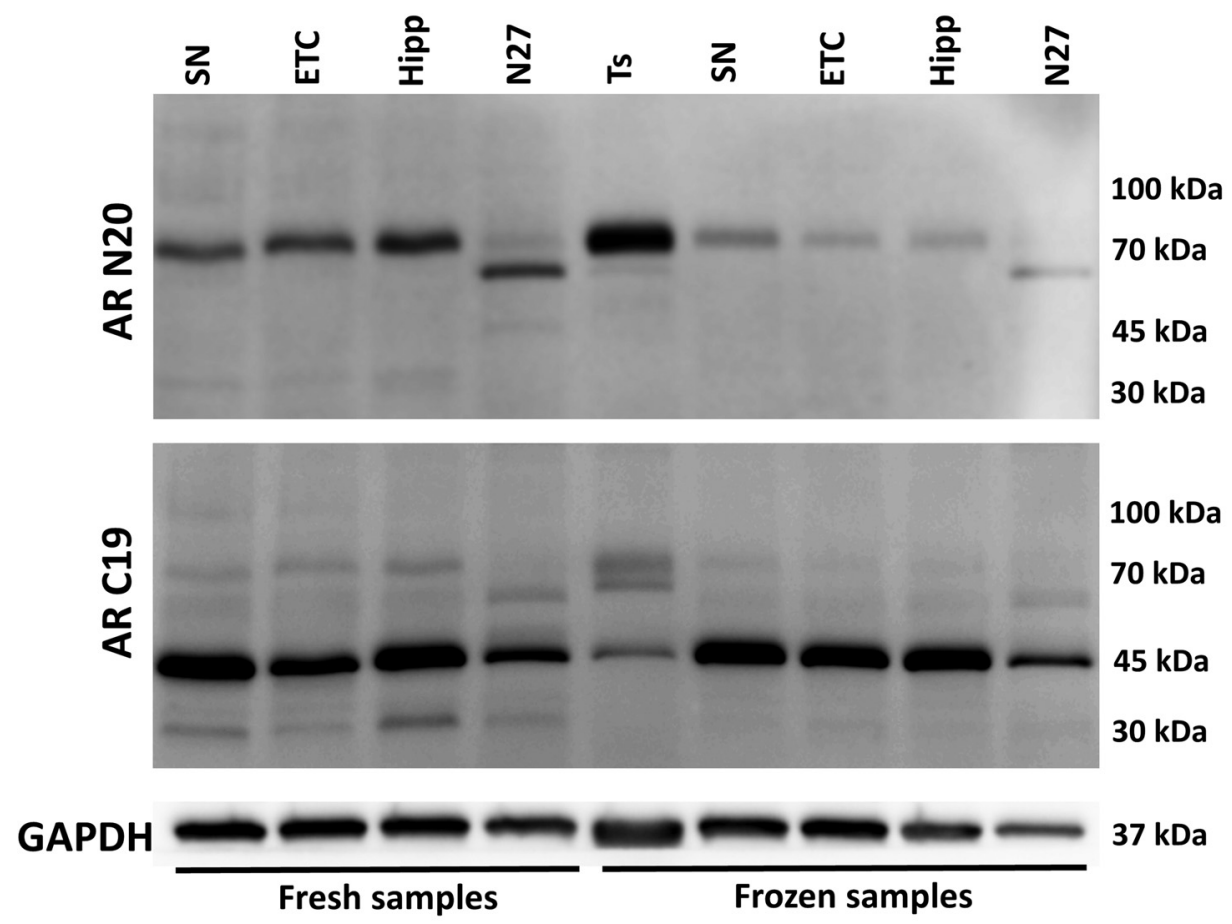

B

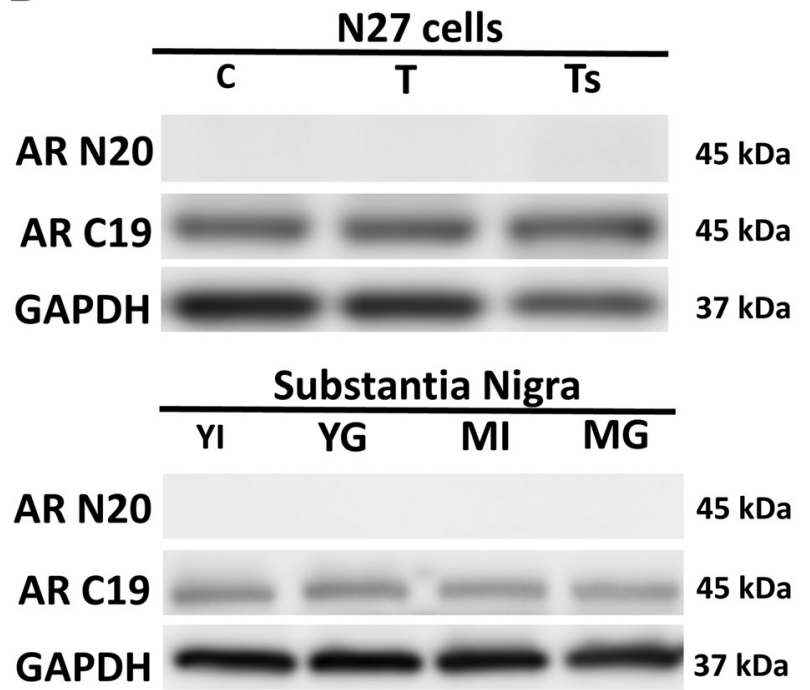

C

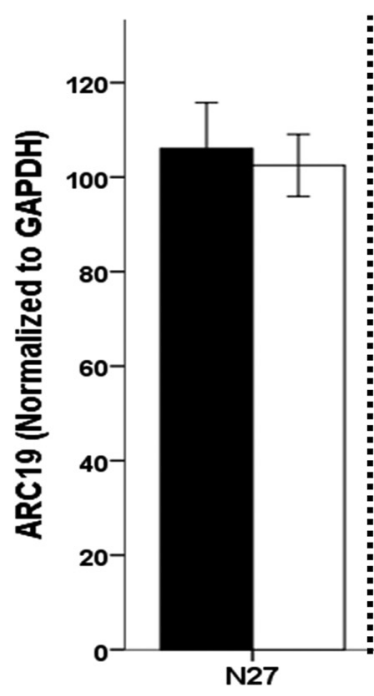

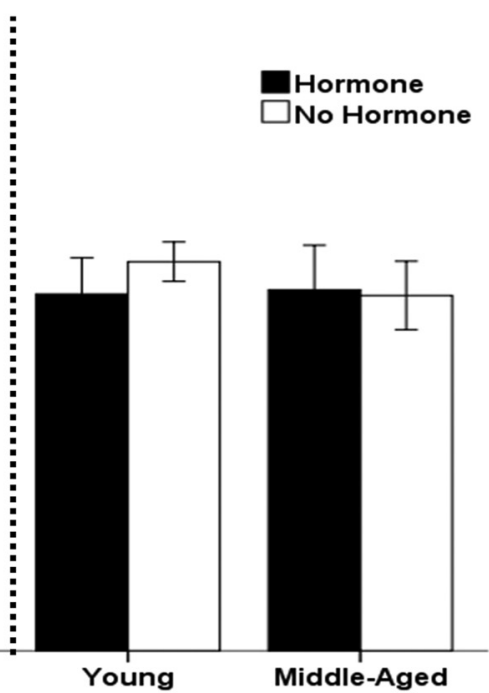

Figure 1. Androgen receptor protein expression. AR protein expression was quantified in N27 cells and SN, ETC, hippocampus, and testes micropunches from young gonadally intact male rats $(n=3)$. Antibodies targeting either the NTD (AR N20) or the CTD (AR C19) of the AR were used. Low protein expression of full-length $A R(110 \mathrm{kDa})$ was found in all samples, but high protein expression of AR fragments $(70$ and $30 \mathrm{kDa}$ ) was observed in fresh samples and to a lesser extent in frozen samples. Protein expression at $45 \mathrm{kDa}$ (AR45) was observed in all samples and was unaffected by temperature $(\boldsymbol{A})$. To determine the role of testosterone and age on AR45 expression, different hormone groups were used: N27 cells treated with vehicle control $(n=8)$ or 100 nM testosterone $(n=8)$ and SN from young and middle-aged male rats that were either gonadectomized $(n=3)$ or gonadally intact $(n=3 ; \boldsymbol{B}$, C). Testosterone did not affect AR45 expression in N27 cells. Neither hormones nor age affected AR45 expression in SN (B, C). C, control; T, testosterone; Ts, testes; YI, young gonadally intact male rats; YG, young GDX male rats; MI, middle-aged gonadally intact male rats; MG, middle-aged GDX male rats; SN, substantia nigra pars compacta; ETC, 2nd layer of the entorhinal cortex; Hipp, CA1 region of the dorsal hippocampus.

amide gel, electrophoresed in Tris-glycine buffer, and transferred onto a PVDF membrane. Membranes were blocked for 30 min with $5 \%$ nonfat milk in TBS-Tween at room temperature. After blocking, membranes were incubated with specific primary antibodies (AR C-19 1:1000, AR N-20 1:750, AR441 1:1000, Androgen R/NR3C4 1:1000, 
Table 1. Primer sequences

\begin{tabular}{|c|c|c|c|}
\hline Target & Primer & Sequence & Size (bp) \\
\hline Exon 1-3 & Exon $1 \mathrm{~F}$ & 5'-GAGGCAGCAGCATACCAGAA-3' & 753 \\
\hline Exon $3 \mathrm{R}$ & 5'-TTTCCGGAGACGACACGATG-3' & & \\
\hline Exon 2-3 & Exon $2 \mathrm{~F}$ & 5'-CAGGGACCACGTTTTACCCA-3' & 229 \\
\hline Exon $3 \mathrm{R}$ & 5'-TTTCCGGAGACGACACGATG-3' & & \\
\hline Exon 3-4 & Exon $3 \mathrm{R}$ & 5'-GACTCTGGGAGCTCGTAAGC-3' & 185 \\
\hline Exon $4 \mathrm{R}$ & 5'-ACACCACTCCTGGCTCAATG-3' & & \\
\hline Exon 4-5 & Exon $4 \mathrm{~F}$ & 5'-GTGCCGGACATGACAACAAC-3' & 281 \\
\hline Exon $5 \mathrm{R}$ & 5'-TCGAGACTTGTGCATGCGAT-3' & & \\
\hline Exon $6-7$ & Exon $6 \mathrm{~F}$ & 5'-AATGTACAGCCAGTGCGTGA-3' & 248 \\
\hline Exon $7 \mathrm{R}$ & 5'-TTGGTGAGCTGGTAGAAGCG-3' & & \\
\hline
\end{tabular}

GAPDH 1:10,000, G $\alpha q$ 1:1000, G $\alpha$ s 1:10,000, G $\alpha i_{1-3}$ 1:10,000, Goo 1:1000, flotillin 1:1000, and caveolin-1 $1: 10,000)$ in TBS-Tween with $1 \%$ nonfat milk for $2 \mathrm{~h}$ or overnight at $4^{\circ} \mathrm{C}$. Afterward, the membranes were washed every $10 \mathrm{~min}$ for $30 \mathrm{~min}$ and incubated with secondary antibodies at 1:1000 in TBS-Tween with 1\% nonfat milk for $30 \mathrm{~min}$ at room temperature. Protein bands on the membrane were visualized using an enhanced chemiluminescence detection assay (Thermo Fisher Scientific). Protein band intensities were imaged using GeneSys software corresponding with the G:Box Chemi XRQ system (Syngene). Protein band densities were quantified by NIH ImageJ densitometer software and normalized to GAPDH for whole-cell lysates, using the equation (mean gray value for protein of interest)/(mean gray value of GAPDH) $\times$ 100. All antibodies used in this study are commercially available. The specificity of the antibodies was assayed by using primary antibodies that were preabsorbed with blocking peptides (N20P 1:50, C19P 1:20) at $4^{\circ} \mathrm{C}$ overnight on representative blots. Previous immunohistochemical studies have shown specificity for AR-C19 and AR N-20 (Kritzer and Creutz, 2008; Holmes et al., 2016).

\section{Immunohistochemistry}

One week after gonadectomy or sham surgery, each rat was anesthetized with Inactin (100 mg/kg, i.p.; Sigma), transcardially flushed with $0.1 \mathrm{M}$ PBS (100-200 ml), and then perfused with $4 \%$ paraformaldehyde in $0.1 \mathrm{M}$ PBS (300-500 ml; Gottlieb et al., 2006; Ji et al., 2007; Cunningham et al., 2011). The brain was removed from the skull and postfixed with $4 \%$ paraformaldehyde in $0.1 \mathrm{M}$ PBS for $24 \mathrm{~h}$. Brains were stored in vials containing $30 \%$ sucrose in PBS at $4^{\circ} \mathrm{C}$ for $3-4 \mathrm{~d}$ before sectioning. Brains were cut into 3 separate sets of $40-\mu \mathrm{m}$ coronal sections using a cryostat (CryoStar NX70, Thermo Fisher Scientific). Coronal sections containing the SN $(-4.80$ to -6.04 $\mathrm{mm}$ from bregma) were blocked with $3 \%$ PBS diluent $(3 \%$ horse serum in PBS with $0.25 \%$ Triton $\mathrm{X}-100$ ) for $2 \mathrm{~h}$ at room temperature followed by overnight incubation at $4{ }^{\circ} \mathrm{C}$ with primary antibody (AR C-19 or AR N-20 at 1:500) in $3 \%$ PBS diluent. Afterward, the sections were washed with PBS. Serial sections incubated with AR C-19 or AR $\mathrm{N}-20$ antibodies were then incubated with secondary antibodies (Alexa Fluor donkey anti-goat 1:1000) at room temperature for $5 \mathrm{~h}$ (Nedungadi et al., 2012). Afterward, sections were washed with PBS. Sections were mounted on slides and sealed with mounting medium. After sealing, the slides were stored at $4^{\circ} \mathrm{C}$. Images were captured from each section using an epifluorescent inverted microscope (VWR) equipped with a digital camera (Photometrics Cool Snap Myo; Nikon) and imaging software (NIS Elements, $\mathrm{Br}$ 4.50.00; Nikon).

\section{RT-PCR}

RNA was extracted from tissue punches of substantia nigra, entorhinal cortex, hippocampus, and confluent N27 cells using a Qiagen RNeasy kit and quantified by spectrophotometry. One microgram of each sample was reverse transcribed using a High Capacity cDNA Reverse Transcription kit from Applied Biosystems. AR intron spanning primers (Table 1) were used for PCR in $100-n g$ equivalents from each $\mathrm{RT}$ reaction over 35 cycles with an annealing temperature of $56^{\circ} \mathrm{C}$ using $300 \mathrm{nM}$ of each primer and GoTaq polymerase (Promega). Negative controls consisted of RT reactions without template. Samples were separated on $1.2 \%$ agarose gels and visualized with ethidium bromide using a Syngene GBox.

\section{Bioassays}

During the first $2 \mathrm{~h}$ of the circadian light phase, each rat was anesthetized with $2.5 \%$ isoflurane and decapitated. Prostate and seminal vesicle wet tissue weights were measured. Trunk blood $(5-7 \mathrm{ml})$ was obtained in EDTAcoated tubes $(13 \times 100 \mathrm{~mm}$, Covidien $)$ on ice. The blood was centrifuged (Allegra X-30R, Beckman Coulter) at $2000 \times g$ for 10 min at $4^{\circ} \mathrm{C}$, then separated plasma was placed in microcentrifuge tubes and stored at $-80^{\circ} \mathrm{C}$ until ELISA analysis for total testosterone. Plasma testosterone levels were assayed according to manufacturer's instructions. The intra-assay coefficient of variation was $8.54 \%$, and the interassay coefficient of variation was $9.97 \%$. The sensitivity of this assay was $0.066 \mathrm{ng} / \mathrm{ml}$ testosterone. The specificity of this assay is 100\% testosterone, $69.6 \%$ dihydrotestosterone (DHT), 7.4\% dihydroxyandrosterone, and $<0.1 \%$ for androstenedione, androsterone, epiandrosterone, dihydroandrosterone, estrone, estradiol, estriol, cortisol, 11-deoxycortisol, progesterone, and $17 \mathrm{OH}$-progesterone.

\section{Statistical analysis}

Analysis was performed using IBM SPSS Statistics, version 21. Data were expressed as mean \pm SEM. Significance $(p \leq 0.05$ ) was determined by ANOVA. 
Table 2. Bioassays

\begin{tabular}{lllllll}
\hline Age & Hormone & $n$ & Body weight & Prostate & Seminal vesicles & Total testosterone \\
Young & GDX & 13 & $325.25 \pm 7.75$ & $0.16 \pm 0.08^{\#}$ & $0.40 \pm 0.18^{\#}$ & $0.36 \pm 0.63^{\#}$ \\
Young & Intact & 13 & $325.35 \pm 27.75$ & $0.46 \pm 0.13$ & $0.83 \pm 0.19$ & $5.61 \pm 2.90$ \\
Middle-aged & GDX & 12 & $444.75 \pm 26.48 *$ & $0.30 \pm 0.11 *^{\#}$ & $0.89 \pm 0.20 *^{\#}$ & $0.21 \pm 0.18^{\#}$ \\
Middle-aged & Intact & 11 & $456.68 \pm 43.96 *$ & $0.75 \pm 0.25 *$ & $1.27 \pm 0.39 *$ & $4.34 \pm 3.42$ \\
\hline
\end{tabular}

Young rats are 3 mo old; middle-aged rats are 9-12 mo old. Weights are expressed as mean $\mathrm{g} \pm \mathrm{SEM}$. Plasma testosterone levels are expressed as mean $\mathrm{ng} / \mathrm{ml} \pm \mathrm{SEM}$. GDX, gonadectomy; intact, gonadally intact. $P<0.05$ : *versus young; "versus intact.

\section{Results}

\section{Bioassays}

Body weights, prostate weights, seminal vesicle weights, and total testosterone levels were quantified (Table 2). Hormone treatment did not have a significant impact on body weight, regardless of age. However, middle-aged rats $(9-12$ mo) were significantly heavier than young rats $\left(3 \mathrm{mo} ; F_{1,45}=233.284, p<0.05\right)$. One week after gonadectomy (GDX), plasma testosterone levels were significantly decreased compared with gonadally intact rats, regardless of age $\left(F_{1,45}=54.221, p<0.05\right)$. No differences in testosterone levels between young and middle-aged gonadally intact rats were observed. Consistent with a decline in testosterone, GDX rats exhibited a significant decrease in weights for androgen-sensitive accessory organs: prostate $\left(F_{1,45}=74.117, p<0.05\right)$ and seminal vesicles $\left(F_{1,45}=33.088, p<0.05\right)$. Middle-aged retired breeders, regardless of hormone condition, had significantly heavier prostate $\left(F_{1,45}=23.577, p<0.05\right)$ and seminal vesicle $\left(F_{1,45}=42.929, p<0.05\right)$ weights than young sexually naive rats. These results are consistent with prior studies showing that sexual experience increases testosterone and androgen-sensitive accessory organ weights (Drori and Folman, 1964; Thomas and Neiman, 1968; Aumüller et al., 1985; Cummings et al., 2013).

\section{Androgen receptor expression}

Androgen receptor expression was quantified in a dopaminergic N27 cell line, along with brain tissue from the substantia nigra pars compacta (SN), second layer of the entorhinal cortex (ETC), and CA1 layer of the dorsal hippocampus from young and middle-aged male rats that were either gonadally intact or GDX (Fig. 1). Frozen and fresh tissue were used, since prior reports found that low temperatures can increase full-length $A R$ fragments (Kemppainen et al., 1992; Gregory et al., 2001). Antibodies targeting either the NTD or CTD of the AR were used to examine AR protein expression. Protein from testes was used as a positive control for AR expression. Low protein expression of full-length $A R(110 \mathrm{kDa})$ was found in all samples using both NTD (AR N20) and CTD (AR C-19) AR antibodies. High protein expression of AR fragments (70 and $30 \mathrm{kDa}$ ) were observed in fresh samples and to a lesser extent in frozen samples (Fig. 1A). These likely represent calpain-dependent proteolysis, as described by Pelley et al. (2006), in human prostate cancer cells. Protein expression at $45 \mathrm{kDa}$ was observed in all samples and was unaffected by temperature. Further, neither hormone nor age altered AR45 protein expression in $\mathrm{N} 27$ cells, $\mathrm{SN}$ tissue, and testes (Fig. $1 B, C$ ). Interestingly, this $45-\mathrm{kDa}$ band was evident only when using a CTD-targeted antibody for the AR and not an NTD antibody, consistent with the AR splice variant AR45 that lacks an NTD. Similar results were observed using different antibodies (AR441 and R/NR3C4) targeting the NTD and CTD of the AR (data not shown).

Widespread CTD AR immunoreactivity (and not NTD AR-positive cells) was observed throughout the $S N$ in young and middle-aged rats, respective of hormone and age status (Fig. 2A, B). AR immunoreactivity included extranuclear staining, suggesting membrane or cytosolic localization. In contrast, the hippocampus and the ETC express both CTD- and NTD-positive AR within the nucleus in young intact males (Fig. $2 \mathrm{C}$ ), consistent with prior immunohistochemical studies using AR antibodies (Sar et al., 1990; Xiao and Jordan, 2002; DonCarlos et al., 2003; Kritzer, 2004).

\section{Expression profile of androgen receptors}

N27 cells and SN brain tissue were split into membrane, cytosol, and nuclear fractions. The membrane portion of both N27 cells and SN brain tissue was further separated into nine fractions using a sucrose gradient (Figs. 3-5). Full-length AR at $110 \mathrm{kDa}$ was not observed in any membrane fraction. Although full-length $A R$ was not expressed, a $45-\mathrm{kDa}$ protein corresponding to AR45 was observed in all samples. In N27 cells, regardless of testosterone exposure, AR45 expression was evident in fractions $3-6$, which are lipid rafts as shown by caveolin-1 and flotillin immunoreactivity (Fig. 3A, B). Similarly, AR45 immunoreactivity was present in caveolin- and flotillinenriched membrane lipid rafts in both young and middleaged rats in all hormone groups (Figs. 4-5). AR45 immunoreactivity was not found in any non-lipid raft portion of the membrane, nor was it observed in cytosolic or nuclear fractions.

\section{Androgen receptor mRNA expression}

RT-PCR for AR was performed to determine whether full-length transcripts were present in SN and N27 cells (Fig. 6). Several intron-spanning primer sets were used to amplify equivalent amounts of CDNA under identical conditions. In the brain, we detected positive signals from all regions examined (SN, ETC, Hipp), confirming the presence of full-length AR mRNA (Fig. 6A, B). However, in N27 cells, we detected no product from an exon 1 to exon 3 primer pair. Exon 2-7 amplicons were detected in N27 cells (Fig. 6B), although the signal was less distinct than in brain samples. These data suggest that full-length $A R$ mRNA is not present in N27 cells, or is present only at very 
A

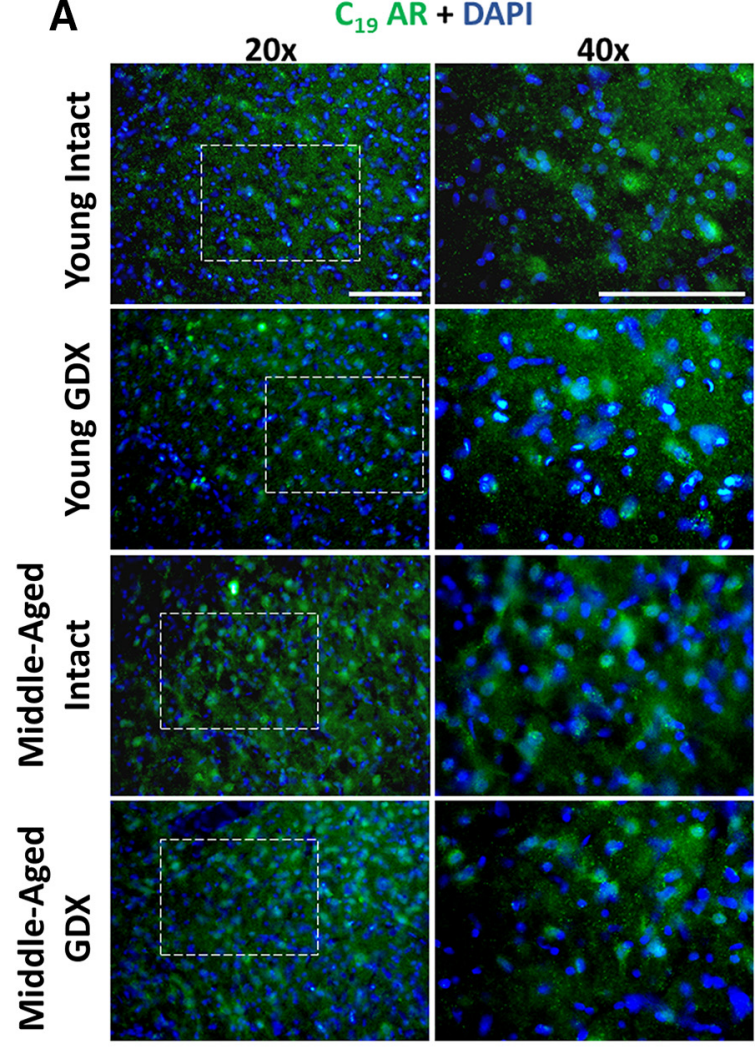

B

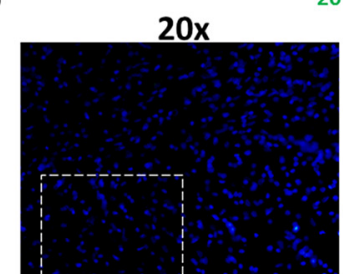

$\mathrm{N}_{20} \mathrm{AR}+\mathrm{DAPI}$

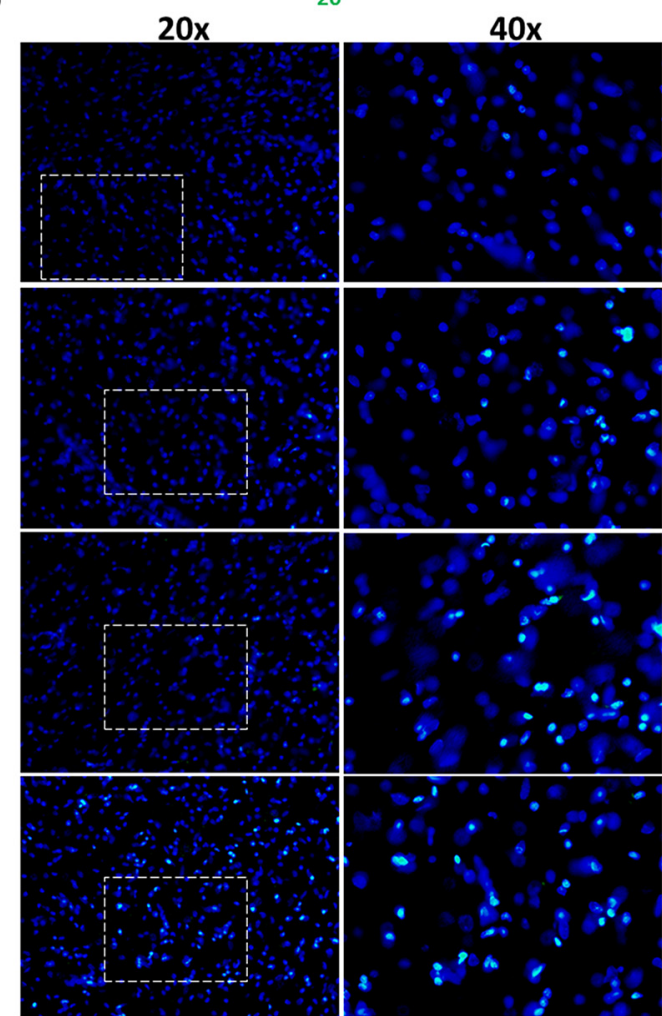

DAPI
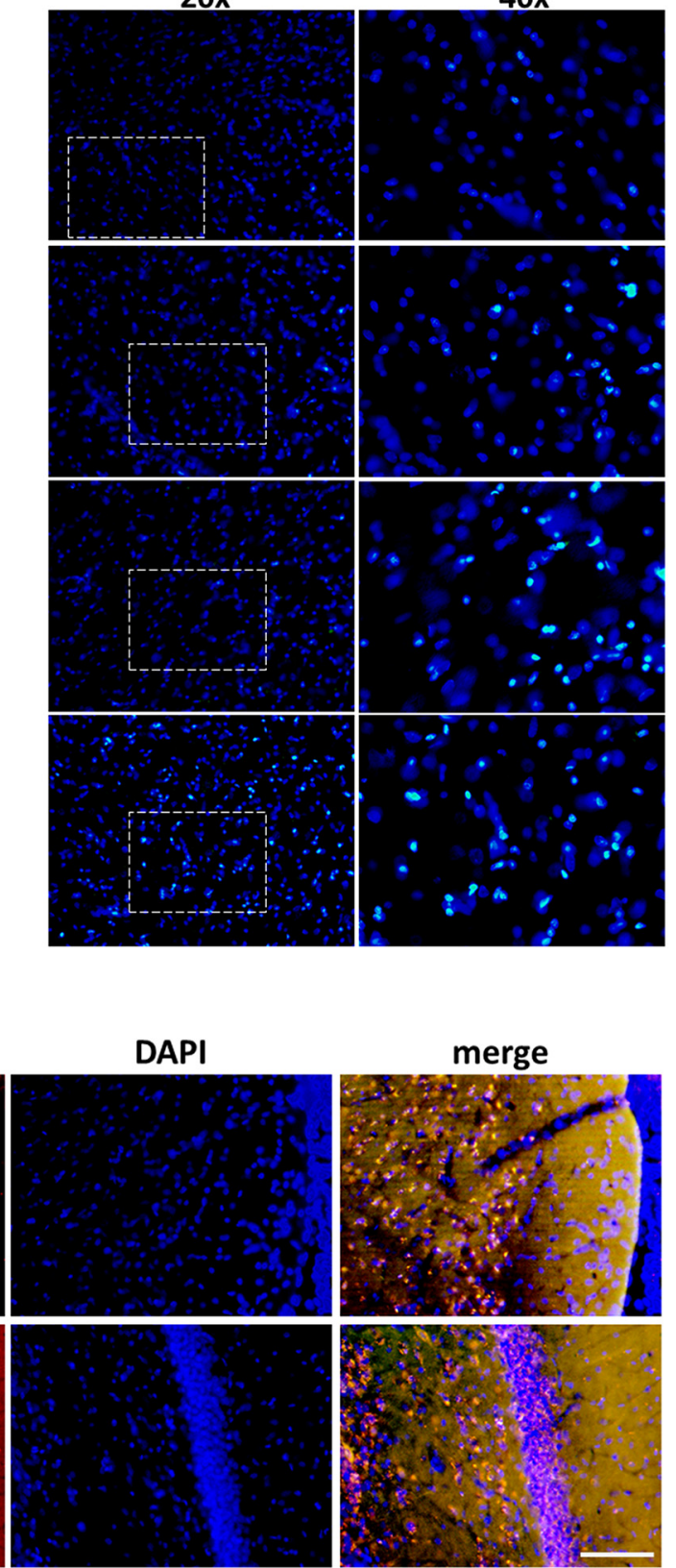

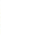

C

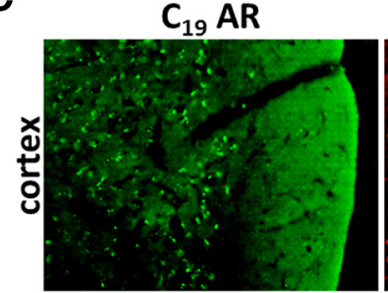

$\mathbf{N}_{20}$ AR
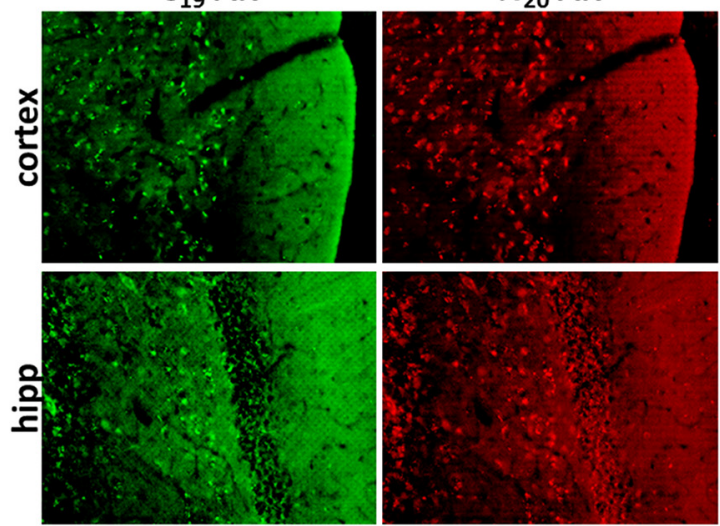

Figure 2. Widespread AR45 distribution in the substantia nigra. AR immunoreactivity using a CTD targeted antibody (AR C19) was observed throughout the SN in all age and hormone groups $(\boldsymbol{A})$. No AR immunoreactivity was observed using a NTD targeted antibody in the SN $(\boldsymbol{B})$. Both the hippocampus and the ETC express CTD and NTD AR immunoreactivity that is present within the nucleus, as evidenced by DAPI colocalization $(\boldsymbol{C})$. SN, substantia nigra pars compacta; ETC, 2nd layer of the entorhinal cortex; Hipp, CA1 region of the dorsal hippocampus. Scale bar $=200 \mu \mathrm{m}$.

low levels, below detectability under our conditions (35 cycles, EtBr detection).

\section{Expression profile of GPCRs in membrane lipid rafts}

Because neuronal mAR has been associated with intracellular calcium signaling (Steinsapir et al., 1991; Gorczynska and Handelsman, 1995; Benten et al., 1999; Estrada et al., 2003, 2006; Holmes et al., 2013), we examined whether $\mathrm{G}$ proteins were present in lipid rafts. In both N27 cells and SN tissue, the G protein $\mathrm{G} \alpha \mathrm{q}$ was expressed in the membrane fraction and in lipid rafts, but $\mathrm{G}_{\alpha \mathrm{i}_{1-3}}$ and $\mathrm{G} \alpha$ s were not expressed in any of the membrane fractions. Interestingly, the $\mathrm{G}$ protein $\mathrm{G} \alpha \mathrm{o}$ was expressed only in SN tissue and not in the N27 cell line (Figs. $3-5)$.

\section{Androgen receptor variant association with GPCR subunits}

To determine whether AR45 interacts with G proteins, coimmunoprecipitation was performed. Antibodies tar- 


\section{A. N27 cells: Vehicle Control}

\begin{tabular}{|c|c|c|c|c|c|c|c|c|c|c|}
\hline Fraction & 1 & 2 & 3 & 4 & 5 & 6 & 7 & 8 & 9 & \\
\hline AR C19 & & & & 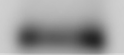 & 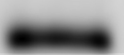 & 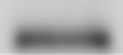 & & & & $45 \mathrm{kDa}$ \\
\hline $\mathrm{G} \alpha_{\mathrm{q}}$ & & $20=$ & 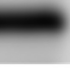 & $=$ & $\mathrm{min}$ & 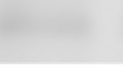 & 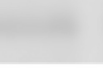 & $=$ & 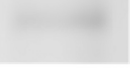 & $45 \mathrm{kDa}$ \\
\hline Caveolin-1 & & & & & & & $\sqrt{15}=$ & & $=$ & $24 \mathrm{kDa}$ \\
\hline Flotillin & & & & & & & & & & $49 \mathrm{kDa}$ \\
\hline
\end{tabular}

\section{B. N27 cells: 24 hour Testosterone (100 nM)}

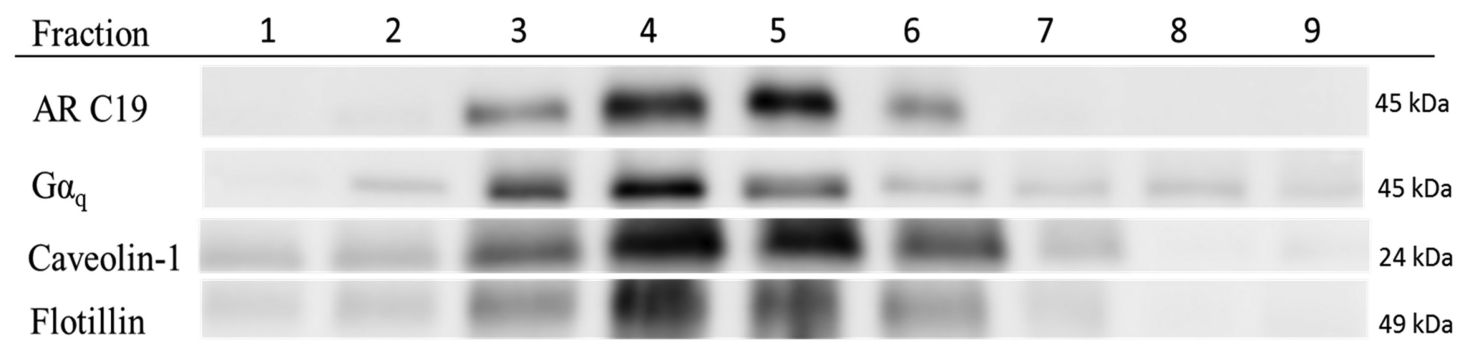

Figure 3. N27 cells express AR45 protein in membrane lipid rafts. N27 cells were treated with either vehicle control $(\boldsymbol{A})$ or $100 \mathrm{nM}$ testosterone for $24 \mathrm{~h}(\boldsymbol{B})$. The membrane portion of the cells were further separated into nine fractions using a sucrose gradient and ultracentrifugation to examine lipid rafts. Primary antibodies targeting AR45 (AR-C19 antibody), G protein G $\alpha$, and lipid raft markers (caveolin-1 and flotillin) were used. AR45 and G $\alpha$ q expression were observed only in lipid raft fractions, as evidenced by caveolin-1 and flotillin expression. Hormone treatment did not alter AR45 and $\mathrm{G} \alpha \mathrm{q}$ expression in lipid rafts. Full-length (110-kDa) AR, G $\alpha 0, \mathrm{G} \alpha \mathrm{i}_{1-3}$, and $\mathrm{G} \alpha \mathrm{s}$ G proteins were not observed in the membranes of N27 cells (data not shown). $n=3$ per treatment group.

geting the CTD of the AR were used to pull down proteins. In a reciprocal fashion to ensure specificity, $\mathrm{G} \alpha \mathrm{q}-$ containing proteins were immunoprecipitated and then immunoblotted for AR45 with an AR C19 antibody. After electrophoresis, membranes were probed for AR45 (C-19 antibody) or G protein immunoreactivity. In N27 cells, AR45 interacted with $\mathrm{G} \alpha \mathrm{q}$, regardless of testosterone exposure (Fig. 7A). Furthermore, in SN tissue, AR45 was associated with $\mathrm{G} \alpha \mathrm{q}$ and $\mathrm{G} \alpha \mathrm{O}$ in all hormone states and ages (Fig. 7B).

\section{Discussion}

This study found AR protein expression at $45-\mathrm{kDa}$ molecular weight in all samples examined: N27 cells, SNpc, hippocampus, ETC, and testes. Furthermore, this AR variant is present in plasma membrane lipid rafts from N27 cells and SN brain tissue from young and middle-aged rats with and without sex hormones. The 45-kDa membrane protein was evident only using a CTD-targeted antibody for AR, consistent with the AR45 splice variant. Interestingly, protein expression of AR45 was not altered by steroid hormones, age, or temperature. Although fulllength AR mRNA was found in all brain samples examined, little to no AR immunoreactivity using the NTDtargeted AR antibody was observed in SNpc tissue, unlike the ETC and hippocampus. Expression profiles for AR immunoreactivity for these brain regions are different, indicating different mechanisms of androgen action in SN versus hippocampus and ETC. This result, coupled with a lack of a detectable exon 1-containing transcript in N27 cells, suggests that the immunoreactive AR45 may represent a bona fide splice variant rather than posttranslational processing of the full-length AR.

Prior studies in young adult and adolescent male Sprague-Dawley rats described AR immunoreactivity in the SNpc using AR antibodies targeting the NTD of the receptor (Kritzer, 1997; Kritzer and Creutz, 2008; PurvesTyson et al., 2012). Our results are consistent with the Kritzer laboratory's findings of low NTD-AR immunoreactivity within the SNpc (only the dorsomedial region) but no AR expression in the rest of the SNpc obtained from young adult male rats. The highest AR immunoreactivity was observed in SN pars lateralis, wherein $>50 \%$ of the neurons are $\mathrm{AR}^{+}$(Kritzer, 1997; Kritzer and Creutz, 2008). These findings indicate that full-length $A R$ is not highly expressed in the SNpc of young adult male rats. In contrast, adolescent male rats have high NTD-AR immunoreactivity in the SNpc, as evidenced by $>65 \%$ of the $\mathrm{TH}^{+}$ neurons immunoreactive for AR (Purves-Tyson et al., 2012). This difference in NTD-AR immunoreactivity between young adult and adolescent male rats could be due to adolescent pruning of $\mathrm{TH}^{+}$neurons in the SNpc (Kuhn et al., 2010). To the best of the authors' knowledge, there are no prior immunohistochemical studies using CTD-AR antibodies in the SN. 


\section{A. Substantia nigra: Young GDX}

\begin{tabular}{|c|c|c|c|c|c|c|c|c|c|c|}
\hline Fraction & 1 & 2 & 3 & 4 & 5 & 6 & 7 & 8 & 9 & \\
\hline AR C19 & & & $\approx 0$ & $x^{2}+x^{2}$ & & & & & & $45 \mathrm{~K}$ \\
\hline $\mathrm{G} \alpha_{\mathrm{q}}$ & 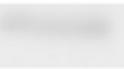 & 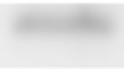 & 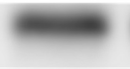 & sing & $x^{2}=$ & 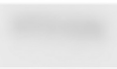 & $x^{2}=$ & $=$ & 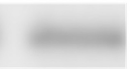 & 45 \\
\hline $\mathrm{G} \alpha_{0}$ & 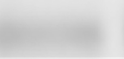 & $x^{2}=$ & e & & r & $x^{2}$ & 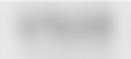 & $x^{2}=$ & $=0$ & 40 \\
\hline Caveolin-1 & & & 2 & r & $=8$ & & & & & $24 \mathrm{k}$ \\
\hline Flotillin & & & & & the & & & & & $49 \mathrm{k}$ \\
\hline
\end{tabular}

\section{B. Substantia nigra: Young Intact}

\begin{tabular}{|c|c|c|c|c|c|c|c|c|c|c|}
\hline Fraction & 1 & 2 & 3 & 4 & 5 & 6 & 7 & 8 & 9 & \\
\hline AR C19 & & & & - & - & - & - & & & $5 \mathrm{kDa}$ \\
\hline $\mathrm{G} \alpha_{\mathrm{q}}$ & 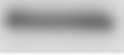 & 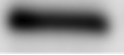 & $=$ & $=$ & $=$ & 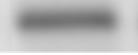 & $=$ & $=$ & $=$ & $45 \mathrm{kDa}$ \\
\hline $\mathrm{G \alpha}_{\mathrm{o}}$ & $\cos =$ & 5 & 0 & 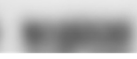 & $\mathrm{e}$ & -2 & 0 & ese & $=$ & $40 \mathrm{kDa}$ \\
\hline Caveolin-1 & & & 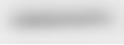 & 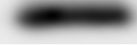 & $=$ & 10 & -20 & & & $4 \mathrm{kDa}$ \\
\hline Flotillin & & & & - & 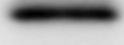 & - & 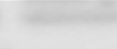 & & & $49 \mathrm{kDa}$ \\
\hline
\end{tabular}

Figure 4. Young male rats express AR45 protein in membrane lipid rafts. Young rats (3 mo old) were either gonadectomized $(\boldsymbol{A})$ or gonadally intact $(\boldsymbol{B})$. Micropunches of substantia nigra tissue were collected, and the membrane was isolated and then separated into nine fractions using a sucrose gradient to examine lipid rafts. Primary antibodies targeting AR45 (AR-C19 antibody), G proteins G $\alpha \mathrm{q}$ and $\mathrm{G} \alpha \mathrm{O}$, and lipid raft markers (caveolin-1 and flotillin) were used. AR45 expression was observed only in lipid raft fractions, as evidenced by caveolin-1 and flotillin expression. Hormone status did not alter AR45 expression in lipid rafts. G $\alpha q$ and $\mathrm{G} \alpha \mathrm{O}$ was observed throughout the membrane, regardless of hormone status. No protein expression of $\mathrm{G}_{\alpha \mathrm{i}_{1-3}}$ and $\mathrm{G} \alpha \mathrm{s} \mathrm{G}$ proteins or full-length (100-kDa) AR was observed in the substantia nigral membranes of young male rats (data not shown). GDX, gonadectomy; intact, gonadally intact. $n=3$ per treatment group.

Because classic full-length AR protein was not highly present in SNpc and N27 cells, it is possible that the AR45 splice variant is mediating androgen's actions in this brain region by acting as an mAR. Prior studies, using nonneuronal cells, have linked AR to membrane lipid rafts (Lu et al., 2001; Cinar et al., 2007; Pedram et al., 2007). Lipid rafts are low-density microdomains, enriched with cholesterol and lipids, and insoluble in non-ionic detergents (Brown and Rose, 1992; Brown and London, 2000). The proteins flotillin and caveolin are integral components of lipid rafts. Neuronal lipid rafts generally are planar and composed of flotillin, unlike nonneuronal cells that contain rafts with invaginations composed of caveolin (Murata et al., 1995; Bickel et al., 1997; Lang et al., 1998). However, studies have shown that caveolin-1 can be present in neurons under certain conditions, such as oxidative stress and aging (Volonté et al., 2001; Kang et al., 2006; Marquet-de Rougé et al., 2013). One of the brain regions with the highest expression of caveolin-1 is the SN (Galbiati et al., 1998), which is composed mainly of dopaminergic $\mathrm{TH}^{+}$neurons that have increased oxidative stress from dopamine metabolism (Lotharius et al., 2002; Hastings, 2009).
Our data showed that AR45 is present in membrane fractions from N27 cells and SN tissue. Specifically, AR45 was present only in caveolin- and flotillin-enriched lipid rafts, indicating localization to lipid rafts that contain invaginations. Although AR45 was expressed only in caveolin $^{+}$lipid rafts, differences were observed in which membrane fractions these proteins localized to. Caveolin was more widespread in the membrane fractions from the N27 cell line, wherein caveolin were observed in lowerdensity protein fractions. Notably, testosterone appeared to shift caveolin expression to higher-density protein fractions in both N27 cells and SN tissue. It is possible that caveolin is undergoing posttranslational modification, resulting in higher-density proteins. Posttranslational modifications (e.g., palmitoylation and phosphorylation) commonly occur in caveolin proteins and steroid receptors (Parat and Fox, 2001; Fukata and Fukata, 2010; Kim et al., 2011). A common initiator of posttranslational modifications in caveolin includes oxidative stress (Kim et al., 2000; Volonté et al., 2001; Wehinger et al., 2015), and testosterone can act as an oxidative stressor (Holmes et al., 2013, 2016). Therefore, it is possible that testosterone, via oxidative stress, is increasing posttranslational 


\section{A. Substantia nigra: Middle-Aged GDX}

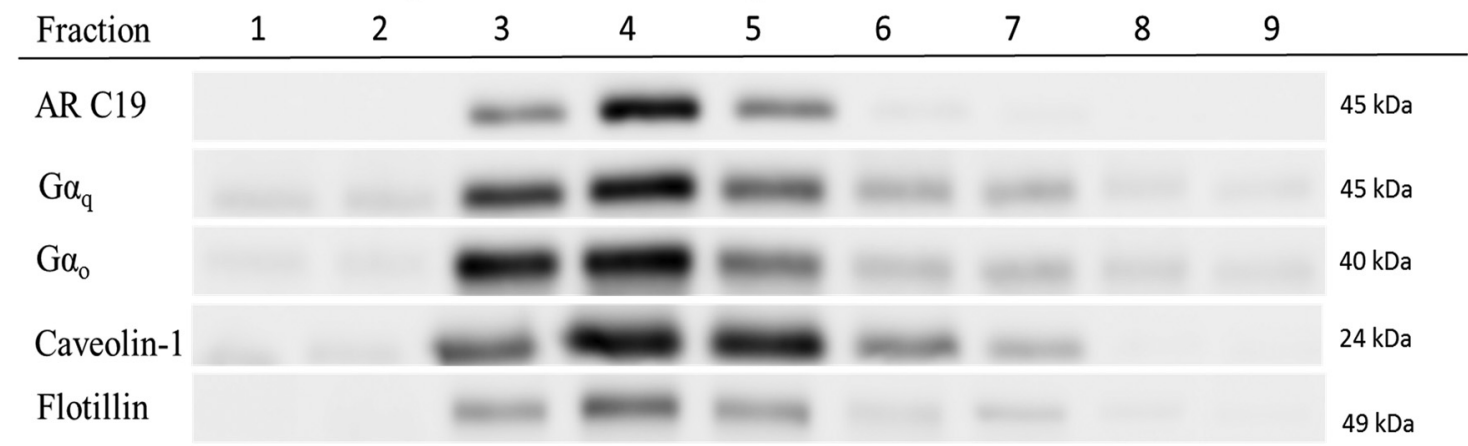

\section{B. Substantia nigra: Middle-Aged Intact}

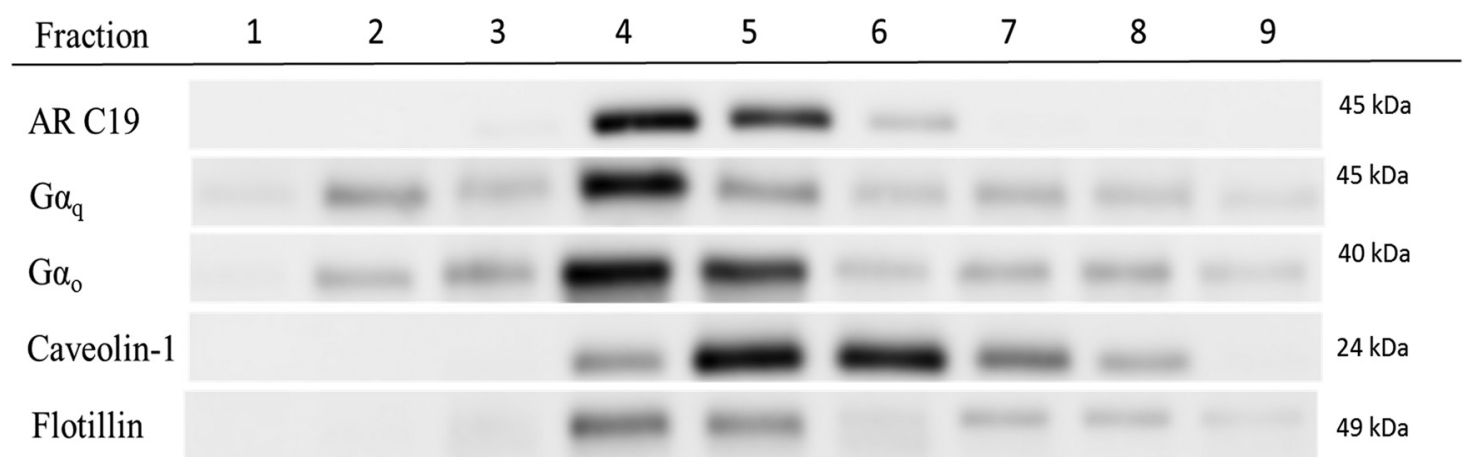

Figure 5. Aged male rats express AR45 protein in membrane lipid rafts. Middle-aged rats (9- to 12-mo old retired breeders) were either gonadectomized $(\boldsymbol{A})$ or gonadally intact $(\boldsymbol{B})$. Membrane portion of the substantia nigra micropunch tissue was isolated, and then separated into nine fractions using a sucrose gradient. AR45 (AR-C19 antibody), G $\alpha \mathrm{q}$ and $\mathrm{G} \alpha \mathrm{O}$, and lipid raft markers (caveolin-1 and flotillin) were examined. AR45 expression was observed only in lipid raft fractions, regardless of hormone status. G $\alpha q$ and $\mathrm{G} \alpha \mathrm{o}$ was observed throughout the membrane in both gonadectomized and gonadally intact males. Protein expression of $\mathrm{G} \alpha \mathrm{i}_{1-3}$, $\mathrm{G} \alpha \mathrm{s}$, or full-length (110-kDa) AR were not observed in the substantia nigral membranes of aged male rats (data not shown). GDX, gonadectomy; intact, gonadally intact. $n=3$ per treatment group.

modifications in caveolin protein, resulting in the caveolin/ AR45 complex shifting to higher-density protein fractions.

Numerous signaling proteins, such as receptor tyrosine kinases, GPCRs, and G proteins, reside in lipid rafts and play a pivotal role in signal transduction (Mineo et al., 1999; Toki et al., 1999; Brown and London, 2000; Lasley et al., 2000; Rybin et al., 2000; Rebois and Hébert, 2003; Pucadyil and Chattopadhyay, 2004; Allen et al., 2005; Xu et al., 2006). Prior studies have shown that $\mathrm{G} \alpha q$ mainly localizes in caveolae lipid rafts, unlike $\mathrm{G} \alpha$ s and $\mathrm{G} \alpha$ i proteins (Murthy and Makhlouf, 2000; Oh and Schnitzer, 2001; Sengupta et al., 2008). Indeed, the results from this study show that $\mathrm{G} \alpha \mathrm{q}$ and $\mathrm{G} \alpha \mathrm{O}$ proteins are present in lipid rafts, along with AR45. Furthermore, AR45 coimmunoprecipitates with $\mathrm{G} \alpha \mathrm{q}$ and $\mathrm{G} \alpha$ o proteins, indicating that $A R 45$ interacts with $G$ proteins in lipid rafts in dopaminergic cells.

$\mathrm{G} \alpha q$ has been well established as an activator of intracellular calcium release from the endoplasmic reticulum (Rhee, 2001; Shi and Kehrl, 2001), which can affect dopaminergic neuronal function in the SNpc (Surmeier et al., 2012). Much less is known about the function of $\mathrm{G} \alpha \mathrm{O}$ proteins that are highly present in frontal cortex, cerebel- lum, hypothalamus, hippocampus, and SN (Worley et al., 1986). $\mathrm{G} \alpha$ o can couple to receptors that decrease intracellular calcium release (Lewis et al., 1986; Hescheler et al., 1987), and in the brain $\mathrm{G} \alpha \mathrm{o}$ is predominantly coupled to inhibitory D2 dopamine receptors (Jiang et al., 2001). Interestingly, this association with $D 2$ receptors may explain the lack of $\mathrm{G} \alpha$ o expression in the N27 cells, as D2 receptors are not expressed in this cell line (Urban and Mailman, 2005). Further supporting the role of $\mathrm{G} \alpha \mathrm{O}$ in SN dopaminergic neuronal involvement, $\mathrm{G} \alpha \mathrm{o}$ knockout mice exhibit poor motor coordination (Jiang et al., 1998). Although data about $\mathrm{G} \alpha \mathrm{O}$ is sparse, $\mathrm{G} \alpha \mathrm{O}$ is linked with motor function and calcium signaling.

Because AR45 appears to be the predominant AR in the $\mathrm{SNpc}$, it may have clinical relevance in the progressive motor disorder Parkinson's disease (PD), resulting from the loss of $\mathrm{TH}^{+}$neurons in the SNpc (Pike et al., 2006, 2009; Cunningham et al., 2009, 2011; Rosario et al., 2011; Holmes et al., 2013, 2016; Verdile et al., 2014). Men have a twofold increased risk for PD than women (Baldereschi et al., 2000). Similarly, postmenopausal women have a greater risk for PD than age-matched premenopausal women (Currie et al., 2004; Ragonese et al., 2006a, 

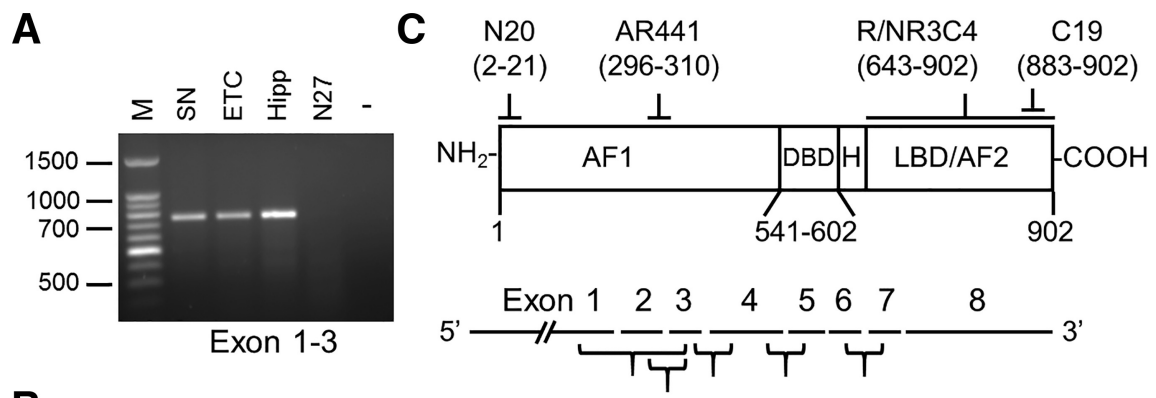

B

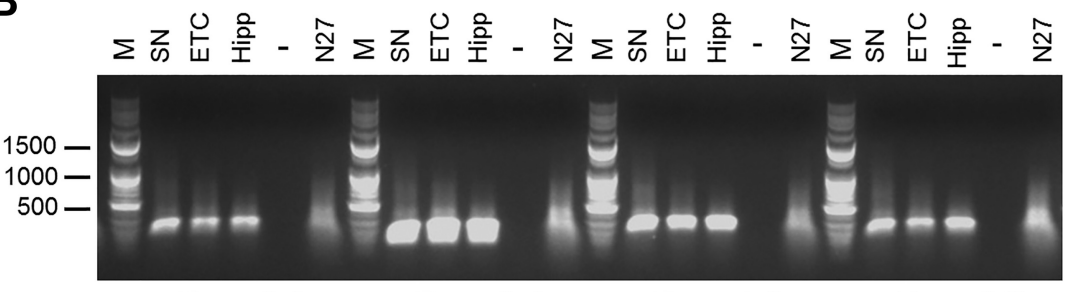

Exon 2-3

Exon 3-4

Exon 4-5

Exon 6-7

Figure 6. Androgen receptor RT-PCR. Intron-spanning primer sets for rat AR were used to amplify cDNA from young intact male rat substantia nigra pars compacta (SN), 2nd layer of the entorhinal cortex (ETC), CA1 region of the hippocampus (Hip), and N27 cells $(\boldsymbol{A}$ and $\boldsymbol{B})$. Note the lack of amplification product for the $3^{\prime}$ region of AR in N27 cells $(\boldsymbol{A})$. $\boldsymbol{C}$, Targets of the antibodies used to detect $A R$ and their epitopes in parentheses aligned with the AR domain structure (top), and the relative amplification product locations in the AR mRNA (bottom). Exons 2 and 3 code for the DBD. M denotes a 100-bp DNA ladder, and negative controls are marked with -.

2006b), which may be due to the higher circulating androgen-to-estrogen state during menopause (Vermeulen, 1976; Laughlin et al., 2000; Liu et al., 2001; Handelsman et al., 2016; Labandeira-Garcia et al., 2016). It is unknown what mechanisms underlie this PD sex difference, but it is possible that AR45 located in dopaminergic membrane caveolin lipid rafts may be involved, especially as upregulated caveolin expression and lipid rafts have been linked with PD (Hashimoto et al., 2003; Trushina et al., 2006; Schengrund, 2010; Sonnino et al., 2014; Cha et al., 2015). Furthermore, recent in vitro studies support the involvement of an mAR in mediating cell viability, oxidative stress generation, and calcium signaling in dopaminergic cells (Estrada et al., 2006; Holmes et al., 2013, 2016), which are key characteristics and processes observed in PD pathology (Jenner et al., 1992; Sherer et al., 2002; Dickson, 2007). Interestingly, both of the in vitro cell lines (N27 and SH-SY5Y cells) are female-derived cell

\section{A. N27 cells}

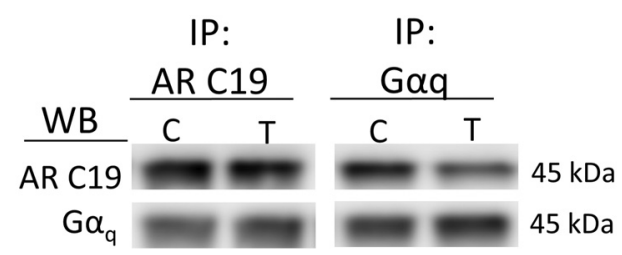

\section{B. Substantia nigra}

\begin{tabular}{|c|c|c|c|c|c|c|c|c|c|}
\hline \multirow[b]{2}{*}{ WB } & \multicolumn{4}{|c|}{ IP: AR C19 } & \multicolumn{4}{|c|}{ IP: Gaq } & \\
\hline & $\mathrm{YI}$ & $Y G$ & $\mathrm{MI}$ & $M G$ & $\mathrm{YI}$ & YG & $\mathrm{MI}$ & MG & \\
\hline AR C19 & $=$ & 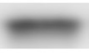 & $m$ & 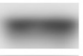 & & & & & $45 \mathrm{kDa}$ \\
\hline $\mathrm{G} \alpha_{\mathrm{q}}$ & 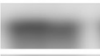 & & & & & & & & $45 \mathrm{kDa}$ \\
\hline $\mathrm{G} \alpha_{\mathrm{o}}$ & 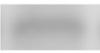 & (n) & & & & & 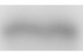 & & $40 \mathrm{kDa}$ \\
\hline
\end{tabular}

Figure 7. Coimmunoprecipitation (IP) of the AR45-G protein complex. Whole-cell lysates of N27 cells treated with either vehicle or 100 $\mathrm{nM}$ testosterone $(\boldsymbol{A})$ and substantia nigral tissue from young and middle-aged male rats that were either gonadectomized or gonadally intact $(\boldsymbol{B})$ were used. AR CTD-containing AR45 proteins were immunoprecipitated and then immunoblotted (WB) for G $\alpha \mathrm{q}$ and G $\alpha$ o. In a reciprocal fashion, $\mathrm{G} \alpha \mathrm{q}$-containing proteins were immunoprecipitated and then immunoblotted for AR45. In N27 cells, bands corresponding to AR45 (AR-C19) and G $\alpha$ q were detectable. In substantia nigral tissue, bands corresponding to AR45 (AR-C19), G $\alpha \mathrm{q}$, and $\mathrm{G} \alpha \mathrm{O}$ were observed. C, control; T, testosterone; YI, young gonadally intact male rats; YG, young GDX male rats; MI, middle-aged gonadally intact male rats; MG, middle-aged GDX male rats. $n=4$ per treatment group. 


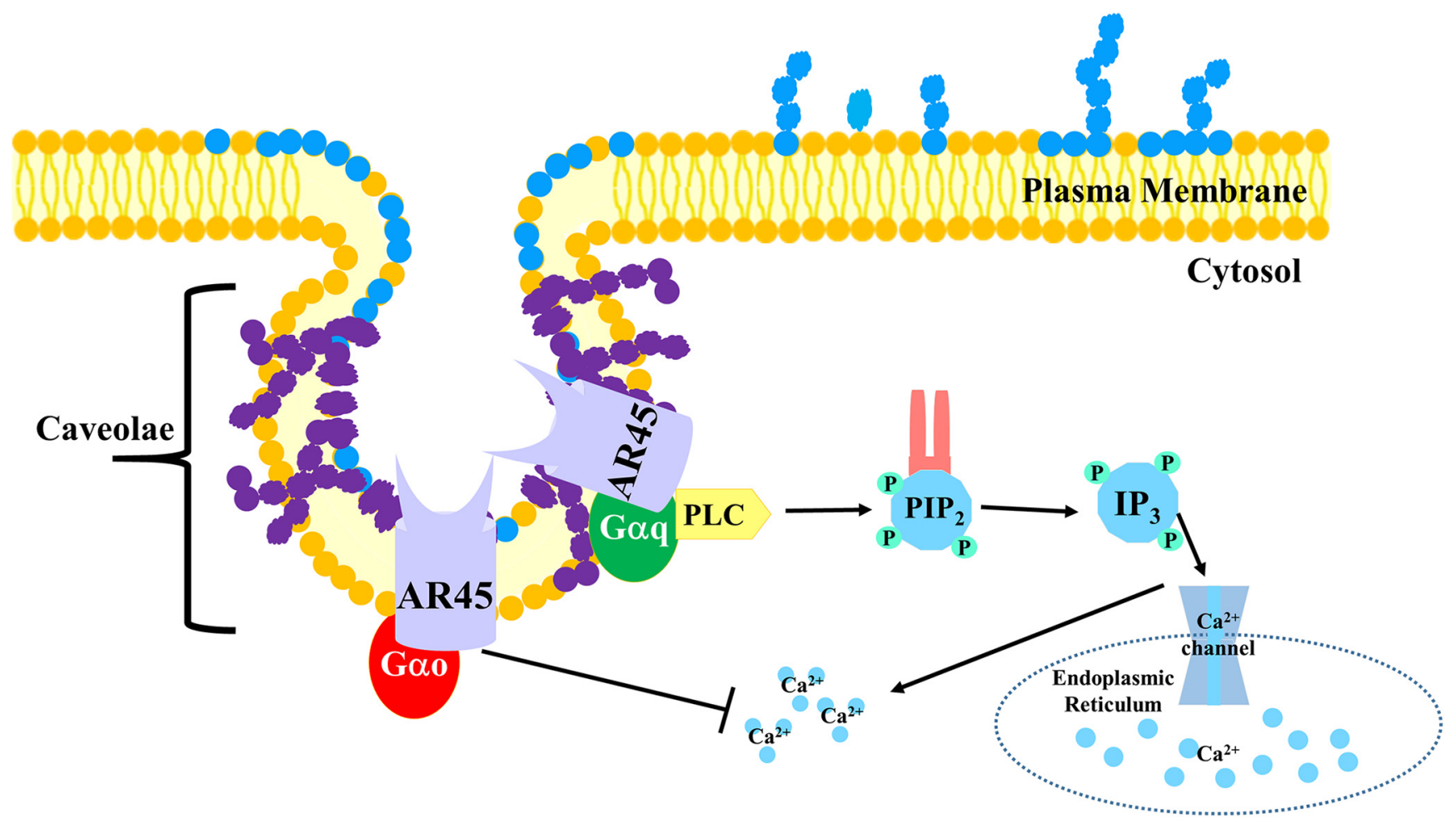

Figure 8. Model. Caveolae lipid rafts are flask-shaped invaginations made up of caveolin (purple) and flotillin (blue) proteins that function by organizing signaling complexes in the plasma membrane. Proteins present in caveolae include AR45. Furthermore, AR45 proteins interact with $\mathrm{G} \alpha \mathrm{q}$ and $\mathrm{G} \alpha$ o proteins, which are involved in modulating intracellular calcium levels. G $\alpha \mathrm{q}$ can increase intracellular calcium release via the PLC/IP3 pathway, whereas G $\alpha$ o can inhibit intracellular calcium. PLC, phospholipase C, IP3: inositol trisphosphate.

lines, indicating that these fast, nongenomic androgen actions in neurons are (1) applicable to both males and females and (2) dependent on the hormonal and AR expression milieu.

This is the first study to show the presence of a putative AR splice variant protein in the SNpc, hippocampus, and ETC brain regions. Specifically, our results show that AR45 localizes in the membrane lipid rafts from N27 cells and SN dopaminergic neurons. Furthermore, AR45 interacts with $\mathrm{G} \alpha \mathrm{q}$ and $\mathrm{G} \alpha \mathrm{o}$ G proteins, which can impact intracellular calcium signaling (Fig. 8). More research needs to be conducted to further determine the function and role of this AR splice variant in dopaminergic neuronal function and dysfunction.

\section{References}

Ahrens-Fath I, Politz O, Geserick C, Haendler B (2005) Androgen receptor function is modulated by the tissue-specific $A R 45$ variant. FEBS J 272:74-84. CrossRef Medline

Allen JA, Yu JZ, Donati RJ, Rasenick MM (2005) Beta-adrenergic receptor stimulation promotes $\mathrm{G}$ alpha $\mathrm{s}$ internalization through lipid rafts: a study in living cells. Mol Pharmacol 67:1493-1504. CrossRef

Anantharam V, Lehrmann E, Kanthasamy A, Yang Y, Banerjee P, Becker KG, Freed WJ, Kanthasamy AG (2007) Microarray analysis of oxidative stress regulated genes in mesencephalic dopaminergic neuronal cells: relevance to oxidative damage in Parkinson's disease. Neurochem Int 50:834-847. CrossRef Medline
Aumüller G, Braun BE, Seitz J, Müller T, Heyns W, Krieg M (1985) Effects of sexual rest or sexual activity on the structure and function of the ventral prostate of the rat. Anat Rec 212:345-352. CrossRef Medline

Baldereschi M, Di Carlo A, Rocca WA, Vanni P, Maggi S, Perissinotto E, Grigoletto F, Amaducci L, Inzitari D (2000) Parkinson's disease and parkinsonism in a longitudinal study: two-fold higher incidence in men. ILSA Working Group. Italian Longitudinal Study on Aging. Neurology 55:1358-1363. CrossRef

Benten WP, Lieberherr M, Stamm O, Wrehlke C, Guo Z, Wunderlich $\mathrm{F}$ (1999) Testosterone signaling through internalizable surface receptors in androgen receptor-free macrophages. Mol Biol Cell 10:3113-3123. Medline

Bickel PE, Scherer PE, Schnitzer JE, Oh P, Lisanti MP, Lodish HF (1997) Flotillin and epidermal surface antigen define a new family of caveolae-associated integral membrane proteins. J Biol Chem 272:13793-13802. Medline

Brown DA, Rose JK (1992) Sorting of GPI-anchored proteins to glycolipid-enriched membrane subdomains during transport to the apical cell surface. Cell 68:533-544. Medline

Brown DA, London E (2000) Structure and function of sphingolipidand cholesterol-rich membrane rafts. J Biol Chem 275:1722117224. CrossRef Medline

Callewaert L, Van Tilborgh N, Claessens F (2006) Interplay between two hormone-independent activation domains in the androgen receptor. Cancer Res 66:543-553. CrossRef Medline

Carvour M, Song C, Kaul S, Anantharam V, Kanthasamy A (2008) Chronic low-dose oxidative stress induces caspase-3-dependent PKCdelta proteolytic activation and apoptosis in a cell culture model of dopaminergic neurodegeneration. Ann N Y Acad Sci 1139:197-205. CrossRef 
Cha SH, Choi YR, Heo CH, Kang SJ, Joe EH, Jou I, Kim HM, Park SM (2015) Loss of parkin promotes lipid rafts-dependent endocytosis through accumulating caveolin-1: implications for Parkinson's disease. Mol Neurodegener 10:63. CrossRef Medline

Cinar B, Mukhopadhyay NK, Meng G, Freeman MR (2007) Phosphoinositide 3-kinase-independent non-genomic signals transit from the androgen receptor to Akt1 in membrane raft microdomains. J Biol Chem 282:29584-29593. CrossRef Medline

Claessens F, Denayer S, Van Tilborgh N, Kerkhofs S, Helsen C, Haelens A (2008) Diverse roles of androgen receptor (AR) domains in AR-mediated signaling. Nucl Recept Signal 6:e008. CrossRef Medline

Clarkson ED, Edwards-Prasad J, Freed CR, Prasad KN (1999) Immortalized dopamine neurons: a model to study neurotoxicity and neuroprotection. Proc Soc Exp Biol Med 222:157-163. Medline

Cummings JA, Clinton SM, Perry AN, Akil H, Becker JB (2013) Male rats that differ in novelty exploration demonstrate distinct patterns of sexual behavior. Behav Neurosci 127:47-58. CrossRef Medline

Cunningham RL, Giuffrida A, Roberts JL (2009) Androgens induce dopaminergic neurotoxicity via caspase-3-dependent activation of protein kinase Cdelta. Endocrinology 150:5539-5548. CrossRef Medline

Cunningham RL, Macheda T, Watts LT, Poteet E, Singh M, Roberts JL, Giuffrida A (2011) Androgens exacerbate motor asymmetry in male rats with unilateral 6-hydroxydopamine lesion. Horm Behav 60:617-624. CrossRef Medline

Currie LJ, Harrison MB, Trugman JM, Bennett JP, Wooten GF (2004) Postmenopausal estrogen use affects risk for Parkinson disease. Arch Neurol 61:886-888. CrossRef Medline

Dickson DW (2007) Linking selective vulnerability to cell death mechanisms in Parkinson's disease. Am J Pathol 170:16-19. CrossRef Medline

Ding D, Xu L, Menon M, Reddy GP, Barrack ER (2004) Effect of a short CAG (glutamine) repeat on human androgen receptor function. Prostate 58:23-32. CrossRef

Ding D, Xu L, Menon M, Reddy GP, Barrack ER (2005) Effect of GGC (glycine) repeat length polymorphism in the human androgen receptor on androgen action. Prostate 62:133-139. CrossRef Medline

DonCarlos LL, Garcia-Ovejero D, Sarkey S, Garcia-Segura LM, Azcoitia I (2003) Androgen receptor immunoreactivity in forebrain axons and dendrites in the rat. Endocrinology 144:3632-3638. CrossRef Medline

Drori D, Folman Y (1964) Effects of cohabitation on the reproductive system, kidneys and body composition of male rats. J Reprod Fertil 8:351-359. Medline

Edwards J, Bartlett JM (2005) The androgen receptor and signaltransduction pathways in hormone-refractory prostate cancer. Part 1: Modifications to the androgen receptor. BJU Int 95:13201326. CrossRef Medline

Estrada M, Uhlen P, Ehrlich BE (2006) Ca2+ oscillations induced by testosterone enhance neurite outgrowth. J Cell Sci 119:733-743. CrossRef Medline

Estrada M, Espinosa A, Müller M, Jaimovich E (2003) Testosterone stimulates intracellular calcium release and mitogen-activated protein kinases via a $\mathrm{G}$ protein-coupled receptor in skeletal muscle cells. Endocrinology 144:3586-3597. CrossRef

Ferro P, Catalano MG, Dell'Eva R, Fortunati N, Pfeffer U (2002) The androgen receptor CAG repeat: a modifier of carcinogenesis? Mol Cell Endocrinol 193:109-120. Medline

Foradori CD, Weiser MJ, Handa RJ (2008) Non-genomic actions of androgens. Front Neuroendocrinol 29:169-181. CrossRef Medline

Fukata Y, Fukata M (2010) Protein palmitoylation in neuronal development and synaptic plasticity. Nat Rev Neurosci 11:161-175. CrossRef Medline

Galbiati F, Volonté D, Gil O, Zanazzi G, Salzer JL, Sargiacomo M, Scherer PE, Engelman JA, Schlegel A, Parenti M, Okamoto T, Lisanti MP (1998) Expression of caveolin-1 and -2 in differentiating PC12 cells and dorsal root ganglion neurons: caveolin-2 is up- regulated in response to cell injury. Proc Natl Acad Sci U S A 95:10257-10262. Medline

Gorczynska E, Handelsman DJ (1995) Androgens rapidly increase the cytosolic calcium concentration in Sertoli cells. Endocrinology 136:2052-2059. CrossRef Medline

Gottlieb HB, Ji LL, Jones H, Penny ML, Fleming T, Cunningham JT (2006) Differential effects of water and saline intake on water deprivation-induced c-Fos staining in the rat. Am J Physiol Regul Integr Comp Physiol 290:R1251-R1261.

Green SM, Mostaghel EA, Nelson PS (2012) Androgen action and metabolism in prostate cancer. Mol Cell Endocrinol 360:3-13. CrossRef Medline

Gregory CW, He B, Wilson EM (2001) The putative androgen receptor-A form results from in vitro proteolysis. J Mol Endocrinol 27:309-319. Medline

Handelsman DJ, Sikaris K, Ly LP (2016) Estimating age-specific trends in circulating testosterone and sex hormone-binding globulin in males and females across the lifespan. Ann Clin Biochem 53:377-384. CrossRef Medline

Hashimoto M, Takenouchi T, Rockenstein E, Masliah E (2003) Alphasynuclein up-regulates expression of caveolin-1 and downregulates extracellular signal-regulated kinase activity in B103 neuroblastoma cells: role in the pathogenesis of Parkinson's disease. J Neurochem 85:1468-1479. Medline

Hastings TG (2009) The role of dopamine oxidation in mitochondrial dysfunction: implications for Parkinson's disease. J Bioenerg Biomembr 41:469-472. CrossRef Medline

Hatzoglou A, Kampa M, Kogia C, Charalampopoulos I, Theodoropoulos PA, Anezinis P, Dambaki C, Papakonstanti EA, Stathopoulos EN, Stournaras C, Gravanis A, Castanas E (2005) Membrane androgen receptor activation induces apoptotic regression of human prostate cancer cells in vitro and in vivo. J Clin Endocrinol Metab 90:893-903. CrossRef Medline

Hescheler J, Rosenthal W, Trautwein W, Schultz G (1987) The GTP_ binding protein, Go, regulates neuronal calcium channels. Nature 325:445-447. CrossRef Medline

Holmes S, Singh M, Su C, Cunningham RL (2016) Effects of oxidative stress and testosterone on pro-inflammatory signaling in a female rat dopaminergic neuronal cell line. Endocrinology 157:28242835. CrossRef

Holmes S, Abbassi B, Su C, Singh M, Cunningham RL (2013) Oxidative stress defines the neuroprotective or neurotoxic properties of androgens in immortalized female rat dopaminergic neuronal cells. Endocrinology 154:4281-4292. CrossRef Medline

Hu DG, Hickey TE, Irvine C, Wijayakumara DD, Lu L, Tilley WD, Selth LA, Mackenzie PI (2014) Identification of androgen receptor splice variant transcripts in breast cancer cell lines and human tissues. Horm Cancer 5:61-71. CrossRef Medline

Hu R, Lu C, Mostaghel EA, Yegnasubramanian S, Gurel M, Tannahill C, Edwards J, Isaacs WB, Nelson PS, Bluemn E, Plymate SR, Luo $\mathrm{J}$ (2012) Distinct transcriptional programs mediated by the liganddependent full-length androgen receptor and its splice variants in castration-resistant prostate cancer. Cancer Res 72:3457-3462. CrossRef Medline

Ikonen T, Palvimo JJ, Jänne OA (1998) Heterodimerization is mainly responsible for the dominant negative activity of amino-terminally truncated rat androgen receptor forms. FEBS Lett 430:393-396. Medline

Jagla M, Fève M, Kessler P, Lapouge G, Erdmann E, Serra S, Bergerat JP, Céraline J (2007) A splicing variant of the androgen receptor detected in a metastatic prostate cancer exhibits exclusively cytoplasmic actions. Endocrinology 148:4334-4343. CrossRef

Jenner P, Dexter DT, Sian J, Schapira AH, Marsden CD (1992) Oxidative stress as a cause of nigral cell death in Parkinson's disease and incidental Lewy body disease. The Royal Kings and Queens Parkinson's Disease Research Group. Ann Neurol 32(Suppl):S82-S87. Medline

Jenster G, van der Korput HA, van Vroonhoven C, van der Kwast TH, Trapman J, Brinkmann AO (1991) Domains of the human androgen 
receptor involved in steroid binding, transcriptional activation, and subcellular localization. Mol Endocrinol 5:1396-1404. CrossRef Medline

Jeske NA, Glucksman MJ, Roberts JL (2003) EP24.15 is associated with lipid rafts. J Neurosci Res 74:468-473. CrossRef Medline

Jeske NA, Glucksman MJ, Roberts JL (2004) Metalloendopeptidase EC3.4.24.15 is constitutively released from the exofacial leaflet of lipid rafts in GT1-7 cells. J Neurochem 90:819-828. CrossRef

Ji LL, Gottlieb HB, Penny ML, Fleming T, Toney GM, Cunningham JT (2007) Differential effects of water deprivation and rehydration on Fos and FosB/DeltaFosB staining in the rat brainstem. Exp Neurol 203:445-456. CrossRef Medline

Jiang M, Spicher K, Boulay G, Wang Y, Birnbaumer L (2001) Most central nervous system D2 dopamine receptors are coupled to their effectors by Go. Proc Natl Acad Sci U S A 98:3577-3582. CrossRef Medline

Jiang M, Gold MS, Boulay G, Spicher K, Peyton M, Brabet P, Srinivasan Y, Rudolph U, Ellison G, Birnbaumer L (1998) Multiple neurological abnormalities in mice deficient in the $G$ protein Go. Proc Natl Acad Sci U S A 95:3269-3274. CrossRef

Kang MJ, Chung YH, Hwang $\mathrm{Cl}$, Murata M, Fujimoto T, Mook-Jung $\mathrm{IH}$, Cha Cl, Park WY (2006) Caveolin-1 upregulation in senescent neurons alters amyloid precursor protein processing. Exp Mol Med 38:126-133. CrossRef Medline

Kelly SJ, Ostrowski NL, Wilson MA (1999) Gender differences in brain and behavior: hormonal and neural bases. Pharmacol Biochem Behav 64:655-664. Medline

Kemppainen JA, Lane MV, Sar M, Wilson EM (1992) Androgen receptor phosphorylation, turnover, nuclear transport, and transcriptional activation. Specificity for steroids and antihormones. J Biol Chem 267:968-974. Medline

Kerr JE, Allore RJ, Beck SG, Handa RJ (1995) Distribution and hormonal regulation of androgen receptor (AR) and AR messenger ribonucleic acid in the rat hippocampus. Endocrinology 136:32133221. CrossRef Medline

Kim W, Bennett EJ, Huttlin EL, Guo A, Li J, Possemato A, Sowa ME, Rad R, Rush J, Comb MJ, Harper JW, Gygi SP (2011) Systematic and quantitative assessment of the ubiquitin-modified proteome. Mol Cell 44:325-340. CrossRef Medline

Kim YN, Wiepz GJ, Guadarrama AG, Bertics PJ (2000) Epidermal growth factor-stimulated tyrosine phosphorylation of caveolin-1. Enhanced caveolin-1 tyrosine phosphorylation following aberrant epidermal growth factor receptor status. J Biol Chem 275:74817491. Medline

Kritzer M (2004) The distribution of immunoreactivity for intracellular androgen receptors in the cerebral cortex of hormonally intact adult male and female rats: localization in pyramidal neurons making corticocortical connections. Cereb Cortex 14:268-280. Medline

Kritzer MF (1997) Selective colocalization of immunoreactivity for intracellular gonadal hormone receptors and tyrosine hydroxylase in the ventral tegmental area, substantia nigra, and retrorubral fields in the rat. J Comp Neur 379:247-260. CrossRef

Kritzer MF, Creutz LM (2008) Region and sex differences in constituent dopamine neurons and immunoreactivity for intracellular estrogen and androgen receptors in mesocortical projections in rats. J Neurosci 28:9525-9535. CrossRef Medline

Kuhn C, Johnson M, Thomae A, Luo B, Simon SA, Zhou G, Walker QD (2010) The emergence of gonadal hormone influences on dopaminergic function during puberty. Horm Behav 58:122-137. CrossRef Medline

Labandeira-Garcia JL, Rodriguez-Perez Al, Valenzuela R, CostaBesada MA, Guerra MJ (2016) Menopause and Parkinson's disease. Interaction between estrogens and brain renin-angiotensin system in dopaminergic degeneration. Front Neuroendocrinol 43: 44-59. CrossRef Medline

Lang DM, Lommel S, Jung M, Ankerhold R, Petrausch B, Laessing U, Wiechers MF, Plattner H, Stuermer CA (1998) Identification of reggie-1 and reggie-2 as plasmamembrane-associated proteins which cocluster with activated GPI-anchored cell adhesion mole- cules in non-caveolar micropatches in neurons. J Neurobiol 37: 502-523. Medline

Lasley RD, Narayan P, Uittenbogaard A, Smart EJ (2000) Activated cardiac adenosine $A(1)$ receptors translocate out of caveolae. $\mathrm{J}$ Biol Chem 275:4417-4421. Medline

Laughlin GA, Barrett-Connor E, Kritz-Silverstein D, von Muhlen D (2000) Hysterectomy, oophorectomy, and endogenous sex hormone levels in older women: the Rancho Bernardo Study. J Clin Endocrinol Metab 85:645-651. CrossRef

Lewis DL, Weight FF, Luini A (1986) A guanine nucleotide-binding protein mediates the inhibition of voltage-dependent calcium current by somatostatin in a pituitary cell line. Proc Natl Acad Sci U S A 83:9035-9039. CrossRef

Link AJ, LaBaer J (2011) Trichloroacetic acid (TCA) precipitation of proteins. Cold Spring Harb Protoc 2011:993-994. CrossRef Medline

Liu Y, Ding J, Bush TL, Longenecker JC, Nieto FJ, Golden SH, Szklo M (2001) Relative androgen excess and increased cardiovascular risk after menopause: a hypothesized relation. Am J Epidemiol 154:489-494. Medline

Lotharius J, Barg S, Wiekop P, Lundberg C, Raymon HK, Brundin P (2002) Effect of mutant alpha-synuclein on dopamine homeostasis in a new human mesencephalic cell line. J Biol Chem 277:3888438894. CrossRef

Lu ML, Schneider MC, Zheng Y, Zhang X, Richie JP (2001) Caveolin-1 interacts with androgen receptor. A positive modulator of androgen receptor mediated transactivation. J Biol Chem 276: 13442-13451. CrossRef Medline

Marquet-de Rougé P, Clamagirand C, Facchinetti P, Rose C, Sargueil F, Guihenneuc-Jouyaux C, Cynober L, Moinard C, Allinquant B (2013) Citrulline diet supplementation improves specific agerelated raft changes in wild-type rodent hippocampus. Age (Dordr) 35:1589-1606. CrossRef Medline

McEwen BS (1980) Binding and metabolism of sex steroids by the hypothalamic-pituitary unit: Physiological implications. Ann Rev Physiol 42:97-110. CrossRef Medline

Mineo C, Gill GN, Anderson RG (1999) Regulated migration of epidermal growth factor receptor from caveolae. J Biol Chem 274: 30636-30643. Medline

Modrek B, Lee C (2002) A genomic view of alternative splicing. Nat Genet 30:13-19. CrossRef Medline

Mooradian AD, Morley JE, Korenman SG (1987) Biological actions of androgens. Endocr Rev 8:1-28. CrossRef Medline

Murata M, Peränen J, Schreiner R, Wieland F, Kurzchalia TV, Simons K (1995) VIP21/caveolin is a cholesterol-binding protein. Proc Nat Acad Sci U S A 92:10339-10343. Medline

Murthy KS, Makhlouf GM (2000) Heterologous desensitization mediated by $G$ protein-specific binding to caveolin. J Biol Chem 275:30211-30219. CrossRef

Nedungadi TP, Dutta M, Bathina CS, Caterina MJ, Cunningham JT (2012) Expression and distribution of TRPV2 in rat brain. Exp Neurol 237:223-237. CrossRef Medline

Oh P, Schnitzer JE (2001) Segregation of heterotrimeric G proteins in cell surface microdomains. G(q) binds caveolin to concentrate in caveolae, whereas $\mathrm{G}(\mathrm{i})$ and $\mathrm{G}(\mathrm{s})$ target lipid rafts by default. Mol Biol Cell 12:685-698. CrossRef

Ozanne DM, Brady ME, Cook S, Gaughan L, Neal DE, Robson CN (2000) Androgen receptor nuclear translocation is facilitated by the f-actin cross-linking protein filamin. Mol Endocrinol 14:1618-1626. CrossRef Medline

Parat MO, Fox PL (2001) Palmitoylation of caveolin-1 in endothelial cells is post-translational but irreversible. J Biol Chem 276:1577615782. CrossRef Medline

Pedram A, Razandi M, Sainson RC, Kim JK, Hughes CC, Levin ER (2007) A conserved mechanism for steroid receptor translocation to the plasma membrane. J Biol Chem 282:22278-22288. CrossRef Medline

Pelley RP, Chinnakannu K, Murthy S, Strickland FM, Menon M, Dou QP, Barrack ER, Reddy GP (2006) Calmodulin-androgen receptor (AR) interaction: calcium-dependent, calpain-mediated break- 
down of AR in LNCaP prostate cancer cells. Cancer Res 66: 11754-11762. CrossRef Medline

Pike CJ, Rosario ER, Nguyen TV (2006) Androgens, aging, and Alzheimer's disease. Endocrine 29:233-241. CrossRef Medline

Pike CJ, Carroll JC, Rosario ER, Barron AM (2009) Protective actions of sex steroid hormones in Alzheimer's disease. Front Neuroendocrinol 30:239-258. CrossRef Medline

Pucadyil TJ, Chattopadhyay A (2004) Cholesterol modulates ligand binding and G-protein coupling to serotonin $(1 \mathrm{~A})$ receptors from bovine hippocampus. Biochim Biophys Acta 1663:188-200. CrossRef Medline

Purves-Tyson TD, Handelsman DJ, Double KL, Owens SJ, Bustamante S, Weickert CS (2012) Testosterone regulation of sex steroid-related mRNAs and dopamine-related mRNAs in adolescent male rat substantia nigra. BMC Neurosci 13:95CrossRef Medline

Ragonese P, D'Amelio M, Savettieri G (2006a) Implications for estrogens in Parkinson's disease: an epidemiological approach. Ann N Y Acad Sci 1089:373-382. CrossRef Medline

Ragonese P, D'Amelio M, Callari G, Salemi G, Morgante L, Savettieri G (2006b) Age at menopause predicts age at onset of Parkinson's disease. Mov Disord 21:2211-2214. CrossRef Medline

Rebois RV, Hébert TE (2003) Protein complexes involved in heptahelical receptor-mediated signal transduction. Receptors Channels 9:169-194. Medline

Rhee SG (2001) Regulation of phosphoinositide-specific phospholipase C. Annu Rev Biochem 70:281-312. CrossRef Medline

Roberts GC, Smith CW (2002) Alternative splicing: combinatorial output from the genome. Curr Opin Chem Biol 6:375-383. Medline

Rosario ER, Chang L, Head EH, Stanczyk FZ, Pike CJ (2011) Brain levels of sex steroid hormones in men and women during normal aging and in Alzheimer's disease. Neurobiol Aging 32:604-613. CrossRef Medline

Rybin VO, Xu X, Lisanti MP, Steinberg SF (2000) Differential targeting of beta-adrenergic receptor subtypes and adenylyl cyclase to cardiomyocyte caveolae. A mechanism to functionally regulate the cAMP signaling pathway. J Biol Chem 275:41447-41457. CrossRef Medline

Sar M, Lubahn DB, French FS, Wilson EM (1990) Immunohistochemical localization of the androgen receptor in rat and human tissues. Endocrinology 127:3180-3186. CrossRef Medline

Sarkey S, Azcoitia I, Garcia-Segura LM, Garcia-Ovejero D, DonCarlos LL (2008) Classical androgen receptors in non-classical sites in the brain. Horm Behav 53:753-764. CrossRef Medline

Schengrund CL (2010) Lipid rafts: keys to neurodegeneration. Brain Res Bull 82:7-17. CrossRef Medline

Sengupta P, Philip F, Scarlata S (2008) Caveolin-1 alters $\mathrm{Ca}(2+)$ signal duration through specific interaction with the $G$ alpha $q$ family of G proteins. J Cell Sci 121:1363-1372. CrossRef

Sherer TB, Betarbet R, Stout AK, Lund S, Baptista M, Panov AV, Cookson MR, Greenamyre JT (2002) An in vitro model of Parkinson's disease: linking mitochondrial impairment to altered alpha-synuclein metabolism and oxidative damage. J Neurosci 22:7006-7015.

Shi CS, Kehrl JH (2001) PYK2 links G(q)alpha and G(13)alpha signaling to NF-kappa B activation. J Biol Chem 276:31845-31850. CrossRef Medline

Smith DF, Toft DO (2008) The intersection of steroid receptors with molecular chaperones: observations and questions. Mol Endocrinol 22:2229-2240. CrossRef Medline

Smith KW, Feldman HA, McKinlay JB (2000) Construction and field validation of a self-administered screener for testosterone deficiency (hypogonadism) in ageing men. Clin Endocrinol (Oxf) 53: 703-711. Medline

Snyder B, Shell B, Cunningham JT, Cunningham RL (2017) Chronic intermittent hypoxia induces oxidative stress and inflammation in brain regions associated with early stage neurodegeneration. Physiol Rep 5:e13258.
Song CS, Rao TR, Demyan WF, Mancini MA, Chatterjee B, Roy AK (1991) Androgen receptor messenger ribonucleic acid (mRNA) in the rat liver: changes in mRNA levels during maturation, aging, and calorie restriction. Endocrinology 128:349-356. CrossRef Medline

Song KS, Li S, Okamoto T, Quilliam LA, Sargiacomo M, Lisanti MP (1996) Co-purification and direct interaction of Ras with caveolin, an integral membrane protein of caveolae microdomains. Detergent-free purification of caveolae microdomains. J Biol Chem 271:9690-9697. CrossRef

Sonnino S, Aureli M, Grassi S, Mauri L, Prioni S, Prinetti A (2014) Lipid rafts in neurodegeneration and neuroprotection. Mol Neurobiol 50:130-148. CrossRef Medline

Stamm S (2002) Signals and their transduction pathways regulating alternative splicing: a new dimension of the human genome. Hum Mol Genet 11:2409-2416. Medline

Steinsapir J, Socci R, Reinach P (1991) Effects of androgen on intracellular calcium of LNCaP cells. Biochem Biophys Res Commun 179:90-96. Medline

Sun S, Sprenger CC, Vessella RL, Haugk K, Soriano K, Mostaghel EA, Page ST, Coleman IM, Nguyen HM, Sun H, Nelson PS, Plymate SR (2010) Castration resistance in human prostate cancer is conferred by a frequently occurring androgen receptor splice variant. J Clin Invest 120:2715-2730. CrossRef Medline

Surmeier DJ, Guzman JN, Sanchez J, Schumacker PT (2012) Physiological phenotype and vulnerability in Parkinson's disease. Cold Spring Harb Perspect Med 2:a009290. CrossRef Medline

Thomas TR, Neiman CN (1968) Aspects of copulatory behavior preventing atrophy in male rats' reproductive system. Endocrinology 83:633-635. CrossRef Medline

Toki S, Donati RJ, Rasenick MM (1999) Treatment of C6 glioma cells and rats with antidepressant drugs increases the detergent extraction of G(s alpha) from plasma membrane. J Neurochem 73:11141120. CrossRef

Trushina E, Du Charme J, Parisi J, McMurray CT (2006) Neurological abnormalities in caveolin-1 knock out mice. Behav Brain Res 172:24-32. CrossRef Medline

Urban JD, Mailman RB (2005) Characterization of the N27 dopaminergic cell line as a potential model for elucidating the mechanisms of action of functionally selective dopamienrgic ligands. In: Society for Neuroscience, Program No. 33.21. Washington DC: Society for Neuroscience.

Verdile G, Laws SM, Henley D, Ames D, Bush Al, Ellis KA, Faux NG, Gupta VB, Li QX, Masters CL, Pike KE, Rowe CC, Szoeke C, Taddei K, Villemagne VL, Martins RN (2014) Associations between gonadotropins, testosterone and beta amyloid in men at risk of Alzheimer's disease. Mol Psychiatry 19:69-75. CrossRef

Vermeulen A (1976) The hormonal activity of the postmenopausal ovary. J Clin Endocrinol Metab 42:247-253. CrossRef Medline

Volonté D, Galbiati F, Pestell RG, Lisanti MP (2001) Cellular stress induces the tyrosine phosphorylation of caveolin-1 (Tyr(14)) via activation of p38 mitogen-activated protein kinase and c-Src kinase. Evidence for caveolae, the actin cytoskeleton, and focal adhesions as mechanical sensors of osmotic stress. J Biol Chem 276:8094-8103. CrossRef Medline

Watson PA, Chen YF, Balbas MD, Wongvipat J, Socci ND, Viale A, Kim K, Sawyers CL (2010) Constitutively active androgen receptor splice variants expressed in castration-resistant prostate cancer require full-length androgen receptor. Proc Natl Acad Sci U S A 107:16759-16765. CrossRef Medline

Wehinger S, Ortiz R, Díaz MI, Aguirre A, Valenzuela M, Llanos P, Mc Master C, Leyton L, Quest AF (2015) Phosphorylation of caveolin-1 on tyrosine-14 induced by ROS enhances palmitate-induced death of beta-pancreatic cells. Biochim Biophys Acta 1852:693708. CrossRef

Weiss B, Faus H, Haendler B (2007) Phylogenetic conservation of the androgen receptor AR45 variant form in placental mammals. Gene 399:105-111. CrossRef Medline

Worley PF, Baraban JM, Van Dop C, Neer EJ, Snyder SH (1986) Go, a guanine nucleotide-binding protein: immunohistochemical local- 
ization in rat brain resembles distribution of second messenger systems. Proc Natl Acad Sci U S A 83:4561-4565. Medline

Wu ZY, Chen K, Haendler B, McDonald TV, Bian JS (2008) Stimulation of $\mathrm{N}$-terminal truncated isoform of androgen receptor stabilizes human ether-a-go-go-related gene-encoded potassium channel protein via activation of extracellular signal regulated kinase 1/2. Endocrinology 149:5061-5069. CrossRef Medline

Xiao L, Jordan CL (2002) Sex differences, laterality, and hormonal regulation of androgen receptor immunoreactivity in rat hippocampus. Horm Behav 42:327-336. Medline
Xu W, Yoon SI, Huang P, Wang Y, Chen C, Chong PL, Liu-Chen LY (2006) Localization of the kappa opioid receptor in lipid rafts. J Pharmacol Exp Ther 317:1295-1306. CrossRef Medline

Yang X, Guo Z, Sun F, Li W, Alfano A, Shimelis H, Chen M, Brodie AM, Chen H, Xiao Z, Veenstra TD, Qiu Y (2011) Novel membraneassociated androgen receptor splice variant potentiates proliferative and survival responses in prostate cancer cells. J Biol Chem 286:36152-36160. CrossRef

Zitzmann M, Brune M, Nieschlag E (2002) Vascular reactivity in hypogonadal men is reduced by androgen substitution. J Clin Endocrinol Metab 87:5030-5037. CrossRef Medline 